\title{
CORPORATE GOVERNANCE, CHARTER VALUE, TIPE KEPEMILIKAN, DAN PENGAMBILAN RISIKO PERBANKAN DI INDONESIA
}

\author{
Hikmatul Fitri \\ Alumni Magister Sains Fakultas Ekonomika \& Bisnis Universitas Gadjah Mada \\ e-mail: Hikmatulfitri.elewa@gmail.com
}

\begin{abstract}
The research examines the influence of corporate governance and charter value on risk taking of registered bank at Indonesian Stock Exchange 2004-2013. Unbalanced panel data is used in this research. Corporate governance is determined by the number of board of commissioners, the percentage of independent commissioners, the quality of risk management, and the total annual coordination meetings of commissioners and board of directors. Tobins' $Q$ is used to measure Charter value. Proxy of risk taking relies on market based measure and accounting based measure. Corporate governance and charter value have shown their role in controlling and maintaining the risk taking in banking system. Foreign and domestic ownerships which dominate their shares in a bank explains the similar risk taking. In fact, both have also demanded a high return. This research has also proved that risk taking conducted by bank management is in line with the risk calculation of accounting based measure. Therefore, it contributes a more consistent result.
\end{abstract}

Key words: corporate governance, charter value, ownership, risk taking, Z-score

\begin{abstract}
Abstrak
Penelitian ini menguji pengaruh corporate governance dan charter value terhadap pengambilan risiko perbankan pada bank yang terdaftar di Bursa Efek Indonesia periode 20042013. Jenis data dalam penelitian ini adalah data panel tidak berimbang. Corporate governance diukur dengan jumlah komisaris, persentase komisaris independen, kualitas manajemen risiko, dan jumlah rapat gabungan komisari dan direksi per tahun. Charter value diukur dengan Tobins' $Q$. Proksi pengambilan risiko yang digunakan adalah berdasarkan data pasar saham (market based measure) dan data akuntansi (accounting based measure). Hasil penelitian ini menunjukkan bahwa corporate governance dan charter value mampu mendisiplinkan pengambilan risiko perbankan. Kepemilikan asing dan domestik sebagai ultimate shareholder di suatu bank, tidak menunjukkan perbedaan terkait pengambilan risiko mereka. Kedua kelompok kepemilikan tersebut menginginkan return yang lebih tinggi. Hasil penelitian ini juga menunjukkan bahwa pengambilan risiko yang dilakukan oleh pihak manajemen bank lebih tercermin dalam pengukuran risiko berdasarkan data akuntansi, karena pengukuran tersebut memberikan hasil yang lebih konsisten.
\end{abstract}

Kata kunci: corporate governance, charter value, tipe kepemilikan, pengambilan risiko, $z$-score

\section{PENDAHULUAN}

Perbankan merupakan industri yang mendapat regulasi tinggi dari pemerintah atau pengawas bank. Hal ini dikarenakan bank merupakan institusi yang terkespos risiko di setiap aktivitas operasionalnya. Greuning dan Bratanovic (2011) menjelaskan bahwa lebih dari $70 \%$ neraca bank, umumnya terkait dengan aspek manajemen risiko. Salah satu yang menjadi faktor timbulnya risiko dalam aktivitas bank adalah risk-taking yang dilakukan oleh manajemen bank.
Banyaknya pemangku kepentingan di dalam aktivitas bisnis perbankan, menjadikan preferensi mereka terhadap risiko juga akan berbeda-beda. Pemegang saham individu lebih menyukai risiko tinggi sebagai akibat pengharapan return yang tinggi pula. Sementara investor institusional memiliki preferensi bagi amannya sebagian besar ekuitas mereka yang terikat di dalam bank, oleh karena itu lebih menginginkan pengambilan risiko yang lebih rendah oleh manajemen bank. Pemerintah akan mengawasi aktivitas bank sehingga tidak melampaui batas maksimum. Pengawas bank 
meregulasi aktivitas bank untuk tidak terlibat dalam pengambilan risiko yang berisiko tinggi. $\mathrm{Hal}$ ini dikarenakan risiko kegagalan bank akan berdampak sistematis bagi kestabilan keuangan suatu negara. Bank juga merupakan institusi yang memiliki asimetri informasi yang tinggi. Asimetri informasi dapat ditemukan di semua sektor, namun permasalahan yang timbul di institusi perantara keuangan akan dipertajam dengan kompleksnya bisnis bank tersebut (Furfine, 2001; Levine, 2004; Morgan, 2002). Hal ini mendorong pemerintah untuk lebih intens mengawasi bisnis bank. Pengawasan tersebut juga dimaksudkan untuk mengurangi perilaku oportunis dan benturan kepentingan. Corporate governance di perbankan lebih menekankan pada peran pengawasan oleh struktur dan fungsi dari dewan komisaris dan kmisaris independen untuk memastikan ke efektifan penerapan corporate governance. Tabel 1 menampilkan komposisi komisaris dan persentase komisaris independen di bank go publicdi Indonesia.

Berdasarkan tabel 1 dapat diketahui bahwa jumlah komisaris pada bank yang terdaftar di BEI selama periode penelitian, memiliki rata-rata jumlah yang tidak jauh berbeda, yaitu rata-rata berkisar 4 orang komisaris. Sementara itu, persentase komisaris independen cenderung mengalami peningkatan dari tahun ke tahun. Tahun 2004 komisaris independen di suatu bank rata-rata hanya $13 \%$ dari jumlah keseluruhan komisaris. Namun di tahun-tahun berikutnya persentase komisaris independen terus mengalami peningkatan, tahun 2013 komisaris independen di bank rata-rata melebihi $50 \%$ dari jumlah komisaris. Hal ini dapat memberi pemahaman bahwa pentingnya peran struktur pengelolaan bagi aktivitas, terkait pengambilan risiko yang dilakukan pihak manajemen, memitigasi risiko potensial yang dihadapi bank di kemudian hari.
Penelitian tentang corporate governance telah dilakukan sebelum krisis finansial dimulai (Mulbert, 2009). Awalnya penekanan dari penerapan corporate governance tersebut lebih diarahkan kepada pencapaian kinerja yang lebih baik bagi perusahaan. Hal tersebut ditandai oleh penelitian-penelitian tentang isu corporate governance yang menguji keefektifan corporate governance terhadap kinerja perbankan (Anderson \& Campbell, 2004; Adams \& Mehran, 2005; Andres \& Vallelado, 2008; Caprio et al., 2007). Namun, di sisi lain yang menarik perhatian adalah, jika penerapan corporate governance akan memberi dampak pada kinerja perusahaan yang lebih baik, maka seharusnya perusahaan tersebut tidak akan goyah ketika terjadi suatu guncangan di lingkungan bisnis, atau dengan kata lain kinerja perusahaan yang lebih baik akan memiliki risiko kegagalan yang lebih rendah pula. Salah satu guncangan yang terjadi di lingkungan bisnis adalah krisis keuangan Asia di tahun 1997 dan bisnis perbankan merupakan entitas yang memiliki dampak buruk atas kejadian tersebut.

Beberapa penelitian menemukan bukti bahwa corporate governance memberi manfaat bagi menurunnya risiko, namun hasil penelitian lain juga menunjukkan hal sebaliknya. Hasil studi yang dilakukan oleh Pathan (2009) menunjukkan bahwa hadirnya dewan komisaris dan komisaris indepeden akan memberi manfaat bagi menurunnya pengambilan risiko yang dilakukan manajemen bank. Hal ini ditandai dengan risiko spesifik dan risiko sistematis yang menurun serta nilai bank yang tetap stabil. Sementara itu, Nguyen (2011) menemukan bahwa corporate governance memiliki pengaruh bagi meningkatnya risk taking perusahaan, ditandai dengan meningkatnya risiko spesifik perusahaan. Salah satu tujuan penelitian ini adalah untuk menguji pengaruh struktur dan fungsi corporate governance terhadap pengambilan risiko tersebut.

Tabel 1: Rata-rata Jumlah Komisaris dan Komisaris Independen Bank yang Terdaftar di Bursa Efek Indonesia periode 2004-2013

\begin{tabular}{cccccc}
\hline Tahun & $\begin{array}{c}\text { Rata-rata Jumlah } \\
\text { Komisaris } \\
\text { (orang) }\end{array}$ & $\begin{array}{c}\text { Rata-rata Komisaris } \\
\text { Independen (persen) }\end{array}$ & Tahun & $\begin{array}{c}\text { Rata-rata Jumlah } \\
\text { Komisaris } \\
\text { (orang) }\end{array}$ & $\begin{array}{c}\text { Rata-rata Komisaris } \\
\text { Independen } \\
\text { (persen) }\end{array}$ \\
\hline 2004 & 4 & 13 & 2009 & 4 & 49 \\
2005 & 5 & 12 & 2010 & 5 & 47 \\
2006 & 4 & 19 & 2011 & 5 & 50 \\
2007 & 4 & 34 & 2012 & 5 & 53 \\
2008 & 4 & 44 & 2013 & 5 & 57 \\
\hline
\end{tabular}

Sumber: Direktori Perbankan Indonesia 
Charter value suatu bank juga akan berkaitan dengan pengambilan risiko. Menurut Keeley (1990) dan Marcus (1984) charter value adalah nilai kapitalisasi dari keuntungan ekonomi bank di masa akan datang. Artinya kemampuan perusahaan dalam mengahasilkan keuntungan dalam aliran kas masa depan. Dalam beberapa literatur disebutkan bahwa charter value merupakan hasil dari imperfect competition dan imperfect loan defaults. Ketika kompetisi rendah, bank membebani biaya pinjaman yang tinggi, mendorong bank melakukan lebih banyak risk taking, sehingga kemungkinan risiko kegagalan bank meningkat. Ketika kompetisi antar bank tinggi, bank mengenakan biaya pinjaman lebih rendah, dan bank terpaksa memiliki pendapatan yang berkurang akibat bank perlu mem-buffer kerugian pinjaman dari kredit macet, sehingga mengakibatkan risiko kegagalan bank juga tinggi (Hellmann et al., 2000; Repullo, 2004; Boyd \& Nicolo 2005; Mierra \& Repullo, 2010).

Hasil penelitian menujukkan bahwa bank yang memiliki charter value yang tinggi akan lebih berhati-hati dalam pengambilam risiko, problem moral hazard dapat teratasi (Acharya, 1996). Niu (2012) menjelaskan bahwa bank akan sangat berhati-hati mengambil risiko sebagai akibat charter value bank yang semakin tinggi, namun sampai di posisi tertentu bank akan menigkatkan risk taking. Hal ini memberi implikasi bahwa charter value suatu bank akan mempengaruhi pilihan keputusan investasi pada proyek berisiko tinggi atau tidak. Di Indonesia penelitian mengenai charter value suatu bank masih sedikit dilakukan, oleh karena itu perlu diteliti lebih lanjut apakah charter value perbankan akan mempengaruhi pengambilan risiko atau tidak.

Hasil penelitian menunjukkan bahwa kepemilikan di dalam suatu institusi ikut mempengaruhi aktivitas di dalamnya. Serangkaian aktivitas tersebut pada akhirnya memiliki implikasi pada proses kinerjanya serta perilaku pengambilan keputusan. Hal tersebut juga terjadi di industri perbankan, identitas kepemilikan di dalam bank akan ikut menentukan pengambilan risiko (Nguyen, 2012; Srairi, 2013; Boubakri et al., 2013; Ianotta, 2013). Bank asing sering berkaitan dengan kinerja yang lebih baik dan profitabilitas yang lebih tinggi (Chen \& Liao, 2011; Nguyen, 2012) dan berkorelasi kuat dengan kinerja yang lebih baik bagi negara-negara berkembang (Micco et al., 2007; Chen \& Liao, 2011). Hasil studi yang dilakukan Chen \& Liao (2011) menemukan bukti bahwa, bank asing dari 12 negara lain termasuk di Indonesia, memiliki kinerja lebih baik relatif terhadap bank domestik. Penelitian juga menunjukkan bahwa kepemilikan asing berdampak pada meningkatnya risk-taking (Nguyen, 2012; Boubakri et al., 2013). Penjelasannya adalah bahwa, untuk memperoleh tingkat pengembalian usaha yang tinggi dan didukung sumber daya yang lebih baik, sangat mungkin bagi mereka untuk melakukan pengambilan aktivitas bisnis yang memiliki risiko tinggi. Penelitian ini juga akan menguji pengaruh pengelolaan perusahaan dan charter value ketika mempertimbangkan tipe kepemilikan.

\section{KAJIAN PUSTAKA}

\section{Penelitian Terdahulu dan Pengembangan Hipotesis}

\section{Pengaruh Corporate Governance terhadap Pengambilan risiko}

Pathan (2009) melakukan studi pada 212 bank holding companies (BHCs) di Amerika Serikat periode 1997-2004 dan menemukan hasil bahwa struktur corporate governance di bank berhubungan dengan menurunnya pengambilan risiko. Hasil tersebut menunjukkan bahwa hadirnya dewan komisaris dan dewan komisaris independen memberi manfaat bagi pengawasan dan pengelolaan bank yang lebih baik, melindungi kepentingan investor dan penyelarasan tujuan pemangku kepentingan. Hal ini ditandai dengan berkurangnya risiko bank.

Andres dan Vallelado (2008) juga mencatat bahwa karakterisitik dan fungsi dewan di perbankan memberi manfaat pada lebih baiknya kinerja bank. Karakteristik dewan diproksikan dengan ukuran dewan dan proporsi dewan independen serta jumlah pertemuan yang diselenggarakan per tahun. Hasil penelitian tersebut menjelaskan bahwa karakteristik dan fungsi dewan di bank memberi manfaat bagi pengwasan dan masukan bagi pihak manajemen sehingga dapat mengurangi asimetri informasi dan meningkatnya kinerja bank. Efektifnya pengawasan dengan hadirnya pihak independen dan dewan di bank dapat menyelaraskan tujuan para pemangku kepentingan, sehingga hal tersebut juga dapat memberi pengawasan bagi tindakan risk taking di 
perbankan. Aebi et al., (2012) melalui studinya juga menemukan bahwa corporate governance yang lebih baik dapat meningkatkan kinerja bank.

Aebi et al., (2012) menggunakan pendekatan risk governance sebagai tambahan, selain menguji struktur corporate governance, untuk menguji perngaruhnya terhadap kinerja bank. Hasil menunjukkan bahwa adanya komite risiko mengindikasikan lebih kuatnya manajemen risiko dan corporate governance yang lebih baik. Pengawasan yang lebih baik dari dewan dan dewan independen akan memberi manfaat bagi meningkatnya kinerja bank. Dengan menggunakan logika tersebut, dapat disimpulkan bahwa komite risiko yang lebih kuat di dalam corporate governance dapat memberi pengawasan bagi perusahaan dan diharapkan dapat mengurangi risk taking. Studi lain yang menguji pengaruh corporate governance terhadap risiko bank dengan konteks Indonesia di antaranya dilakukan oleh Tandelilin et al., (2007). Hasil penelitian memberikan bukti bahwa corporate governance berpengaruh negatif terhadap risiko bank. Penelitia dilakukan periode 1999 -2004 dengan 51 bank yang beroperasi di Indonesia. Berdasarkan pengujian data sekunder, diperoleh bahwa bank yang memiliki CAR yang tinggi mengindikasikan corporate governance yang lebih baik sehingga akan berhubungan negatif terhadap risiko. Sama halnya hasil pengujian dari data primer, ditemukan bukti bahwa corporate governance berhubungan positif dengan manajemen risiko bank. Artinya adalah bank yang memiliki skor tinggi untuk manajemen risiko dapat dinyatakan bahwa bank memiliki implementasi yang baik bagi pengelolaan risikonya.

$\mathrm{H}_{1 \mathrm{a}}$ : Jumlah komisaris berpengaruh negatif terhadap pengambilan risiko di perbankan

$\mathrm{H}_{1 \mathrm{~b}}$ : Persentase komisaris independen berpengaruh negatif terhadap pengambilan risiko di perbankan

$\mathrm{H}_{1 \mathrm{c}}$ : Kualitas manajemen risiko berpengaruh negatif terhadap pengambilan risiko di perbankan

$\mathrm{H}_{1 \mathrm{~d}}$ : Jumlah rapat gabungan komisaris dan direksi berpengaruh negatif terhadap pengambilan risiko di perbankan
Pengaruh Corporate Governance terhadap Pengambilan risiko Bank Berdasarkan Tipe Kepemilikan

Penelitian mengenai pengaruh corporate governance dan pengambilan risiko memberikan hasil beragam saat peneliti mempertimbangkan faktor kepemilikan, seperti kepemilikan oleh manajerial (Saunders, 1990; Levine \& Laeven, 2009) kepemilikan terkonsentrasi (Ianotta et al., 2007), tipe kepemilikan seperti pihak asing, domestik, pemerintah, dan swasta (Tandelilin et al., 2007; Nguyen, 2012; Ianotta et al., 2013). Laeven dan Levine (2009) menemukan bukti bahwa pengaruh bank governance terhadap risk-taking akan berbeda bergantung pada struktur kepemilikan bank. Bank dengan kepemilikan yang lebih powerful atau memiliki kekuasaan cenderung mengambil risiko yang lebih tinggi. Pemegang ekuitas memiliki dorongan yang lebih kuat untuk meningkatkan pengambilan risiko dibandingkan dengan manajer tanpa kepemilikan saham dan pemegang hutang, serta pemegang saham besar dengan aliran kas yang substansial memiliki kekuasaan dan dorongan untuk mempengaruhi manajer bank untuk meningkatkan pengambilan risiko.

Studi yang dilakukan Tandelilin et al., (2007) menemukan bukti bahwa tipe kepemilikan berpengaruh terhadap risiko bank. Bank yang dimiliki oleh pihak asing berpengaruh negatif terhadap risiko. Artinya, kelompok bank yang kepemilikannya oleh pihak asing memiliki pengelolaan yang lebih baik sehingga memberi manfaat bagi menurunnya risiko bank. Regresi interaksi dummi tipe kepemilikan bank oleh pihak asing sebagai variabel pemoderasi akan memperlemah hubungan negatif antara corporate governance dan Value at Risk (VaR). Bukti empiris lain yang ditemukan Nguyen (2012) juga mencatat bahwa kepemilikan oleh investor asing memberi pengaruh positif bagi risk taking perusahaanperusahaan di Jepang periode 1998-2007.

Hasil dari penelitian ini dapat disimpulkan bahwa tipe kepemilikan di perusahaan menjadi penggerak fundamental dari risktaking-nya perusahaan. Berdasarkan argumen yang dijelaskan pada hasil penelitian terdahulu, bahwa kepemilikan di suatu perusahaan terutama bank, secara substansial menjadi pendorong bagi bank untuk melakukan investasi pada aktivitas yang memiliki tingkat risiko 
lebih tinggi atau tidak. Bank dengan kepemilikan oleh pihak asing sering berhubungan dengan pengelolaan yang lebih baik, inovasi dan ekspektasi return yang lebih tinggi, oleh karena itu mereka memiliki dorongan mengambil risiko yang lebih tinggi pula. Bank yang kepemilikan asing lebih tinggi sering berkaitan dengan organisasi yang lebih besar, memiliki human capital dengan kompetensi tinggi serta ekspaktriat yang lebih berpengalaman di bidang jasa keuangan (Chen \& Liao, 2012). Mereka memiliki kemampuan kontrol jauh lebih tinggi dan corporate governance yang lebih baik, sehingga lebih mampu mengelola risiko yang mungkin timbul di masa akan datang, oleh karenanya mereka juga lebih menyukai aktivitas investasi atau proyek yang lebih berisiko.

$\mathrm{H}_{2 \mathrm{a}}$ : Kepemilikan asing akan memperlemah hubungan negatif antara jumlah komisaris dan pengambilan risiko di perbankan

$\mathrm{H}_{2 \mathrm{~b}}$ : Kepemilikan asing akan memperlemah hubungan negatif antara persentase komisaris independen dan pengambilan risiko di perbankan

$\mathrm{H}_{2 \mathrm{c}}$ : Kepemilikan asing akan memperlemah hubungan negatif antara kualitas manajemen risiko dan pengambilan risiko di perbankan

$\mathrm{H}_{2 \mathrm{~d}}$ : Kepemilikan asing akan memperlemah hubungan negatif antara rapat gabungan komisaris dan direksi dan pengambilan risiko di perbankan

$\mathrm{H}_{3 \mathrm{a}}$ : Kepemilikan domestik akan memperkuat hubungan negatif antara jumlah komisaris dan pengambilan risiko di perbankan

$\mathrm{H}_{3 \mathrm{~b}}$ : Kepemilikan domestik akan memperkuat hubungan negatif antara persentase komisaris independen dan pengambilan risiko di perbankan

$\mathrm{H}_{3 \mathrm{c}}$ : Kepemilikan domestik akan memperkuat hubungan negatif antara kualitas manajemen risiko dan pengambilan risiko di perbankan

$\mathrm{H}_{3 \mathrm{~d}}$ : Kepemilikan domestik akan memperkuat hubungan negatif antara rapat gabungan komisaris dan direksi dan pengambilan risiko di perbankan

\section{Pengaruh Charter Value Bank Terhadap Pengambilan Risiko}

Hasil studi yang dilakukan Cebenoyan et al., (1999) menemukan bukti bahwa terdapat hubungan negatif antara charter value dan keputusan pengambilan risiko. Hal ini menunjukkan bahwa bank dengan charter value yang lebih tinggi akan mengurangi keterlibatan mereka dalam aktivitas atau investasi yang tidak profitable atau dengan kata lain lebih berhati-hati dalam pengambilan risiko.

Saunders \& Wilson (2001) menemukan hasil studi bahwa charter value berasal dari aktivitas risiko yang lebih tinggi. Hal tersebut mengindikasikan bahwa dengan membatasi risk taking mereka berarti akan membatasi charter value suatu bank. Dengan kata lain, bank akan meningkatkan pengambilan risiko sebagai keinginan mereka untuk meningkatkan charter bank. Penelitian ini menggunakan data bank selama seratus tahun, yaitu periode 18931992 untuk menganalisis balance sheet spesifik bank dan data pasar. Hasil penelitian menunjukkan bahwa charter value yang tinggi berdampak positif bagi pengambilan risiko. Penjelasannya adalah selama masa ekspansi, kesempatan bertumbuh bagi bank lebih besar sehingga mereka mengambil banyak kesempatan investasi untuk meningkatkan charter value mereka. Charter value bank yang tinggi memberikan akses yang lebih mudah untuk sumber modal ekuitas bagi ekspansi. Sebaliknya, pada masa ekonomi menurun dan stagnan terjadi hubungan positif antara risiko leverage bank dan charter value. Gonzalez (2005) menemukan bahwa dengan mengurangi charter value bank, maka akan berhubungan positif dengan pengambilan risiko. Artinya bahwa, ketika bank memiliki dorongan untuk terlibat dalam proyek yang berisiko tinggi, mereka akan menurunkan charter value mereka. Studi tersebut dilakukan di 251 bank di 36 negara dengan menitikberatkan pada dampak regulasi bank atas charter value dan pengambilan risiko. Hasil studi juga mengonfirmasi bahwa charter value bank yang tinggi akan mengurangi dorongan bank untuk terlibat dalam aktivitas berisiko tinggi.

Gosh (2009) menemukan bukti kuat bahwa charter value bank-bank di India dapat memberi manfaat mendisiplinkan bank dalam pengambilan risiko. Charter value diukur dengan penjumlahan nilai pasar ekuitas dan nilai buku hutang dikurang nilai buku aset, dan pengambilan risiko diukur dengan beberapa aspek yang berbeda, yaitu absolute capital buffer bank untuk mengukur jarak risiko 
kegagalan bank, rasio non-performing loans (NPL) untuk mengukur risiko aset bank, dan Zscore untuk mengukur tingkat kesehatan bank. Hasil studi tersebut memberi kesimpulan bahwa semakin tinggi nilai pasar ekuitas maka bank akan lebih berhati-hati dalam pengambilan risiko mereka.

$\mathrm{H}_{4}$ : Charter value bank berpengaruh negatif terhadap pengambilan risiko di perbankan

Pengaruh Charter Value terhadap Pengambilan Risiko Bank Berdasarkan Tipe Kepemilikan

Cebenoyan et al. (1999) menemukan bahwa pengaruh charter value terhadap pengambilan risiko akan berbeda pada bank yang sahamnya dimiliki oleh pihak institusional dan manajerial. Regresi yang tidak menggunakan struktur kepemilikan sebagai variabel pemoderasi menunjukkan hasil bahwa charter value bank berpengaruh positif terhadap pengambilan risiko bank. Namun, ketika terdapat variabel moderasi kepemilikan oleh insider, pengaruh charter value adakalanya (periode penelitian) menjadi negatif dan signifikan terhadap risiko. Berarti, semakin tinggi charter value bank dan persentase kepemilikan bank oleh pihak insider maka akan semakin rendah dorongan bank tersebut untuk mengambil risiko yang lebih tinggi dan semakin berhati-hati untuk berperilaku terkait pengambilan risiko untuk menjaga nilai charter bank. Hal tersebut selain dikarenakan manajer atau direktur akan ikut menanggung risiko di masa akan datang, manajer dan direktur lebih memproteksi karir dan reputasi mereka sehingga mereka mengambil risiko relatif lebih rendah. Berdasarkan hasil penelitian tersebut dapat disimpulkan bahwa pengambilan risiko di bank akan berbeda apabila identitas kepemilikan dipertimbangkan. Peneliti berekspektasi bahwa bank dengan kepemilikan asing lebih tinggi, di mana mereka merupakan organisasi dengan modal lebih besar, lebih inovatif, memiliki keahlian dan kemampuan pengelolaan bank yang lebih baik sehingga lebih menyukai proyek berisiko tinggi, akan memperlemah hubungan negatif antara charter value dan pengambilan risiko bank. Berdasarkan hal tersebut, maka peneliti merumuskan hipotesis:

$\mathrm{H}_{5 \mathrm{a}}$ : Kepemilikan asing akan memperlemah hubungan negatif antara charter value dan pengambilan risiko bank

$\mathrm{H}_{5 \mathrm{~b}}$ : Kepemilikan domestik akan memperkuat hubungan negatif antara charter value dan pengambilan risiko bank

\section{METODE PENELITIAN}

\section{Sampel Penelitian}

Penelitian ini menggunakan 38 bank yang terdaftar di Bursa Efek Indonesia periode 20042012. Data yang digunakan adalah data panel tidak seimbang dengan jumlah observasi 380 . Namun jumlah sampel dan jumlah observasi akan berbeda pada pengujian berdasarkan data pasar saham. Hal tersebut disebabkan tidak terdapatnya informasi data saham bank sampel atau belum aktif diperdagangkan. Jumlah bank menjadi 36 dengan jumlah observasi berbedabeda bergantung pada proksi risikonya.

Tabel berikut menampilkan proksi variabel yang digunakan dalam penelitian ini.

\begin{tabular}{|c|c|}
\hline Variabel & Pengukuran \\
\hline \multicolumn{2}{|l|}{ Panel A Variabel } \\
\hline \multicolumn{2}{|l|}{ Independen } \\
\hline \multicolumn{2}{|l|}{ 1. Corporate Governance } \\
\hline Komisaris & Jumlah komisaris di bank \\
\hline Komisaris Independen & $\begin{array}{l}\text { Persentase komisaris, yaitu komisaris tanpa hubungan lainnya dengan } \\
\text { perusahaan keculai sebagai jabatan komisaris }\end{array}$ \\
\hline Kualitas Manajemen & Jumlah anggota pemantau risiko dikalikan dengan masa jabatannya di bank \\
\hline Risiko & sampel \\
\hline Rapat Gabungan & $\begin{array}{l}\text { Jumlah pertemuan dewan komisaris dan direksi yang diadakan perusahaan } \\
\text { selama satu tahun }\end{array}$ \\
\hline 2. Charter Value & Nilai pasar aset dibag nilai buku aset \\
\hline \multicolumn{2}{|l|}{ Panel B Variabel } \\
\hline \multicolumn{2}{|l|}{ Dependen } \\
\hline $\begin{array}{l}\text { 1. Risiko Insolvency (Z- } \\
\text { score) }\end{array}$ & $\begin{array}{l}\text { Jumlah return on asset dan earning to asset dibagi dengan deviasi standar } \\
\text { return on asset }\end{array}$ \\
\hline
\end{tabular}




\begin{tabular}{|c|c|}
\hline Variabel & Pengukuran \\
\hline 2. Risiko Sistematis & $\begin{array}{l}\text { Nilai kuadrat koefisien } \mathrm{R}_{\mathrm{Mt}}\left(\text { yaitu } \beta_{\mathrm{i}}\right) \text { dikalikan varians return pasar pada } \\
\text { persamaan SIM }\end{array}$ \\
\hline 3. Risiko Spesifik & $\begin{array}{l}\text { Varians return saham harian dikali nilai residual dari persamaan regresi } \\
\text { SIM }\end{array}$ \\
\hline 4. Risiko Total & Deviasi standar return saham harian per tahun \\
\hline 5. Beta & Koefisien dari persamaan regresi SIM \\
\hline 6. $\mathrm{VaR}$ & $\begin{array}{l}\text { Sensitivitas risiko terhadap perubahaan harga saham pada tingkat keyakinan } \\
\text { tertentu }\end{array}$ \\
\hline 7. Volatilitas ROA & Deviasi standar return on asset kuartalan \\
\hline \multicolumn{2}{|l|}{ Panel C Variabel } \\
\hline \multicolumn{2}{|l|}{ Pemoderasi } \\
\hline 1. Kepemilikan Asing & Persentase kepemilikan oleh pihak asing sebagai ultimate shareholder \\
\hline 2. Kepemilikan Domestik & Persentase kepemilikan oleh pihak domestik sebagai ultimate shareholder \\
\hline Panel D Variabel Kontrol & \\
\hline $\begin{array}{l}\text { Non-Performing Loans } \\
\text { (NPL) }\end{array}$ & Jumlah kredit bermasalah dibagi jumlah kredit yang disalurkan \\
\hline $\begin{array}{l}\text { Loan to Deposit Ratio } \\
\text { (LDR) }\end{array}$ & Jumlah pinjaman yang disalurkan dibagi jumlah dana pihak ketiga \\
\hline Cost to Income (CI) & Total beban operasional bank dibagi total pendapatan \\
\hline
\end{tabular}

\section{Model Pengujian Hipotesis}

Pengujian hipotesis pertama dilakukan berdasarkan model berikut:

$Y_{i t}=\beta_{1}+\beta_{2} C G_{i t}+\sum_{h=1}^{3} \gamma_{h} X_{h i t}+\varepsilon_{i t}$

Pengujian hipotesis kedua dan ketiga menggunakan model berikut:

$$
\begin{aligned}
Y_{i t}= & \beta_{1}+\beta_{2} C G_{i t}+\beta_{3} F O_{i t}+\beta_{4} C G_{i t} * F O_{i t}+ \\
& \sum_{h=1}^{3} \gamma_{h} X_{h i t}+\varepsilon_{i t} \\
Y_{i t}= & \beta_{1}+\beta_{2} C G_{i t}+\beta_{3} D O_{i t}+\beta_{4} C G_{i t} * D O_{i t}+ \\
& \sum_{h=1}^{3} \gamma_{h} X_{h i t}+\varepsilon_{i t}
\end{aligned}
$$

Model pengujian hipotesis keempat menggunakan adalah sebagai berikut:

$Y_{i t}=\beta_{1}+\beta_{2} C V_{i t}+\sum_{h=1}^{3} \gamma_{h} X_{h i t}+\varepsilon_{i t}$

Model pengujian hipotesis kelima menggunakan adalah sebagai berikut:

$$
\begin{aligned}
Y_{i t}= & \beta_{1}+\beta_{2} C V_{i t}+\beta_{3} F O_{i t}+\beta_{4} C V_{i t} * F O_{i t}+ \\
& \sum_{h=1}^{3} \gamma_{h} X_{h i t}+\varepsilon_{i t} \\
Y_{i t}= & \beta_{1}+\beta_{2} C V_{i t}+\beta_{3} D O_{i t}+\beta_{4} C V_{i t} * D O_{i t}+ \\
& \sum_{h=1}^{3} \gamma_{h} X_{h i t}+\varepsilon_{i t}
\end{aligned}
$$

$\mathrm{Y}_{\text {it }}$ merupakan variabel pengukuran risiko, $\mathrm{CG}_{\mathrm{it}}$ merupakan pengukuran corporate governance yaitu jumlah komisaris, persentase komisaris independen, kualitas manajemen risiko, dan rapat gabungan komisaris dan direksi per tahun. $\mathrm{CV}_{\text {it }}$ merupakan variabel charter value, $\mathrm{FO}_{\mathrm{it}}$ merupakan persentase kepemilikan asing, $\mathrm{DO}_{\mathrm{it}}$ merupakan persentase kepemilikan domestik. Variabel $\mathrm{X}_{\text {hit }}$ merupakan variabel kontrol rasio non-performing loans, loan to deposit, dan cost to income.

\section{HASIL PENELITIAN DAN PEMBAHASAN Statistik Deskriptif}

Berdasarkan hasil pengumpulan data terhadap variabel-variabel penelitian diperoleh rata-rata jumlah komisaris di bank sebanyak 4 orang, dan 38\% dari jumlah komisaris di bank merupakan komisaris independen. Kualitas manajemen risiko rata-rata bank sampel bernilai 9, nilai yang lebih tinggi menunjukkan kualiatas yang lebih baik. Jumlah rapat gabungan rata-rata diadakan 2 kali selama setahun. Nilai rata-rata charter value bank sampel adalah 1,10, kepemilikan asing sebagai ultimate shareholder rata-rata adalah 69\%, sementara kepemilikan domestik rata-rata adalah 63\%. Rasio kredit bermasalah (NPL) bank sampel rata-rata sebesar 3,5\%. Rata-rata rasio likuiditas (LDR) adalah 85\%. Rata-rata nilai Z-score adalah 4,89, dengan nilai maksimum sebesar 8,68. Risiko spesifik ratarata bank sampel adalah 0,41 , rata-rata $\mathrm{VaR}$ adalah 0,86 . Hasil selengkapnya seperti yang ditampilkan pada Tabel 2 berikut. 
Tabel 2: Statistik Deskriptif Variabel-variabel Penelitian

\begin{tabular}{|c|c|c|c|c|c|c|}
\hline Variabel & $\begin{array}{c}\text { Jumlah } \\
\text { Observasi }\end{array}$ & $\begin{array}{c}\text { Jumlah } \\
\text { Bank }\end{array}$ & $\begin{array}{c}\text { Nilai } \\
\text { Rata- } \\
\text { rata }\end{array}$ & $\begin{array}{l}\text { Deviasi } \\
\text { Standar }\end{array}$ & Minimum & Maksimum \\
\hline \multicolumn{7}{|c|}{ Panel A: Corporate Governance, Charter Value, dan Tipe Kepemilikan } \\
\hline Komisaris (KOM) & 379 & 38 & 4,4829 & 2,0345 & 1,0000 & 10,0000 \\
\hline $\begin{array}{l}\text { Persentase Komisaris } \\
\text { Independen (KOM_INDP) }\end{array}$ & 377 & 38 & 0,3818 & 0,2602 & 0,0000 & 1,0000 \\
\hline $\begin{array}{l}\text { Kualitas Manajemen Risiko } \\
\text { (KUALITAS) }\end{array}$ & 192 & 38 & 9,0034 & 7,4115 & 0,4000 & 45,5000 \\
\hline $\begin{array}{l}\text { Rapat Gabungan Komisaris \& } \\
\text { Direksi (RAPAT) }\end{array}$ & 129 & 38 & 2,2039 & 0,7454 & 0,0000 & 4,2047 \\
\hline Charter Value (CV) & 273 & 36 & 1,1051 & 0,2024 & 0,0994 & 1,7518 \\
\hline Kepemilikan Asing (FO) & 87 & 38 & 0,6938 & 0,1992 & 0,1150 & 0,9999 \\
\hline Kepemilikan Domestik (DO) & 293 & 38 & 0,6308 & 0,2305 & 0,1319 & 1,0000 \\
\hline \multicolumn{7}{|l|}{ Panel B: Pengukuran Risiko } \\
\hline Risiko Insolvency (Z-score) & 348 & 38 & 4,8983 & 1,1624 & 0,1921 & 8,6828 \\
\hline Risiko Sistematis $\left(\beta^{2} \sigma_{\mathrm{m}}{ }^{2}\right)$ & 152 & 36 & 0,2723 & 0,4041 & 0,0003 & 3,1548 \\
\hline Risiko Spesifik $\left(\sigma_{\mathrm{e}}^{2}\right)$ & 249 & 36 & 0,4059 & 0,6251 & $\begin{array}{c}0,0000002 \\
5\end{array}$ & 3,7773 \\
\hline Beta saham $\left(\beta_{\text {SIM }}\right)$ & 157 & 36 & 0,8731 & 0,3982 & $-0,3811$ & 1,8724 \\
\hline Value at Risk (VaR) & 263 & 36 & 0,8655 & 1,3201 & $-1,4645$ & 6,3639 \\
\hline \multicolumn{7}{|l|}{ Panel C: Variabel Kontrol } \\
\hline Non-Performing Loans (NPL) & 348 & 38 & 0,0358 & 0,0497 & 0,0002 & 0,5100 \\
\hline Loan to Deposit Ratio (LDR) & 379 & 38 & 0,8542 & 2,1071 & 0,0068 & 41,5400 \\
\hline Cost to Income $(\mathrm{CI})$ & 379 & 38 & 0,8927 & 0,6497 & 0,0079 & 12,2600 \\
\hline
\end{tabular}

Sumber: Data Diolah

\section{Pengujian Hipotesis}

Hasil pengujian terhadap hipotesis $1_{\mathrm{a}}-1_{\mathrm{d}}$ (Lampiran 1) menunjukkan bahwa jumlah komisaris, komisaris independen, kualitas manajemen risiko, dan jumlah rapat gabungan komisaris dan direksi berpegaruh positif terhadap Z-score dan berpengaruh negatif terhadap risiko sistematis, risiko spesifik, dan $\mathrm{VaR}$. Semakin tinggi jumlah komisaris memberi manfaat bagi meningkatnya kestabilan bank (Z-score tinggi). Hal tersebut sesuai dengan hasil studi Pathan (2009) pada bankbank besar di Amerika dan studi Tandelilin et al. (2007) di bank go-public Indonesia. Hadirnya dewan komisaris dan khususnya komisaris independen akan menyeimbangkan kepentingan pemegang saham dan para pemangku kepentingan lainnya di bank termasuk deposan dan pembuat kebijakan atau pengawas bank. Menurunnya risiko bank akan tercermin di dalam spesifik individu bank dan kondisi pasar secara keseluruhan.

Hasil uji $\mathrm{H}_{2 \mathrm{a}}-\mathrm{H}_{2 \mathrm{~d}}$ menunjukkan bahwa kepemilikan asing yang lebih tinggi akan

\footnotetext{
${ }^{1}$ Tabel-tabel hasil pengujian hipotesis dilampirkan
}

memperlemah hubungan negatif antara jumlah komisaris dan pengambilan risiko untuk pengukuran risiko sistematis tanpa variabel kontrol, memperlemah hubungan negatif antara persentase komisaris independen dan risiko sistematis, serta memperlemah hubungan negatif kualitas manajemen risiko dan rapat gabungan komisaris dan direksi terhadap risiko spesifik bank. Hal ini berarti bahwa, investor memandang kepemilikan asing sebagai ultimate shareholder di bank sering berkaitan dengan semakin tingginya risk taking yang dilakukan oleh bank tersebut. Hal ini mengindikasikan bahwa, terdapat karakteristik khusus pada bank-bank tersebut, sehingga risiko spesifik bank tersebut juga lebih tinggi. Hasil ini sejalan dengan penelitian Tandelilin et al.,(2007), Laeven dan Levine (2009), Nguyen (2012) dan Boubakri et al., (2013), bahwa identitas kepemilikan berpengaruh pada pengambilan risiko bank.

Hasil uji $\mathrm{H}_{3 \mathrm{a}}-\mathrm{H}_{3 \mathrm{~d}}$ menunjukkan bahwa persentase kepemilikan domestik yang lebih tinggi di bank akan memperlemah hubungan corporate governance dan risiko untuk berbagai pengukuran risiko. Hipotesis kepemilikan 
bank domestik akan memperkuat hubungan negatif antara corporate governance dan pengambilan risiko di bank tidak terdukung. Hal ini tidak mendukung hasil penelitian Nguyen (2012) namun mendukung hasil penelitian Tandelilin et al., (2007) dan sejalan dengan hasil penelitian Laeven \& Levine (2009). Untuk konteks Indonesia, bank yang dimiliki oleh pihak domestik dengan persentase lebih tinggi tidak terbukti dapat memperkuat hubungan negatif antara corporate governance dan risk-taking di perbankan. ketika mempertimbangkan tipe kepemilikan sebagai ultimate shareholder, investor atau pemegang saham akan mendorong perusahaan untuk melakukan investasi pada risiko yang lebih tinggi sebagai akibat pengharapan atas return yang lebih tinggi. Hasil uji $\mathrm{H}_{4}$ menunjukkan bahwa charter value berpengaruh negatif terhadap pengambilan risiko untuk risiko sistematis, spesifik, dan berpengaruh positif terhadap VaR, serta berhubungan positif dengan $Z$-score. Hal ini mendukung penelitian Niu (2012), Gosh (2009), Cebenoyan et al. (1999), dan Acharya (1996). Bank dengan charter value yang tinggi akan lebih berhati-hati dalam melakukan risktaking dalam rangka menjaga nilai perusahaan mereka. Hasil uji $\mathrm{H}_{5 \mathrm{a}}$ menunjukkan bahwa bank dengan kepemilikan asing lebih tinggi akan lebih disiplin dalam risk-taking mereka sebagai usaha mempertahankan nilai charter mereka, sehingga nilai kestabilan bank tetap terjaga dan mengurangi risiko insolvency. Hal ini tidak mendukung hipotesis $\mathrm{H}_{5 \mathrm{a}}$. Hasil penelitian juga menunjukkan kepemilikan domestik yang lebih tinggi akan memperlemah hubungan charter value dan Z-score. Bank yang memiliki ultimate shareholder pihak domestik akan lebih terlibat dalam kegiatan-kegiatan investasi lebih berisiko, seperti aktivitas diversifikasi bank. Hal ini akan mengurangi nilai kestabilan bank dan meningkatkan risiko insolvency. Namun, untuk pengukuran risiko berdasarkan data pasar, persentase kepemilikan domestik sebagai ultimate shareholder akan memperkuat hubungan negatif charter value dan risiko sistematis serta VaR. Risk-taking yang dilakukan oleh bank tidak dipengaruhi oleh kondisi pasar, kemungkinan risiko dari volatilitas harga saham yang diterima oleh investor juga relatif rendah (VaR).

\section{PENUTUP}

Berdasarkan hasil penelitian dapat disimpulkan bahwa struktur dan fungsi corporate governance memberi manfaat bagi menurunnya risiko bank, baik yang diproksikan diukur berdasarkan data akuntansi maupun data pasar. Hal ini berarti bahwa, pengelolaan perusahaan yang lebih baik dapat mengurangi permasalahan agensi di dalam perbankan, mampu menyelaraskan tujuan para pemangku kepentingan termasuk pemerintah dan pengawas bank, yang bertujuan untuk menjaga stabilitas sistem keuangan negara. Preferensi terhadap risiko berdasarkan tipe kepemilikan bank tidak jauh berbeda antara kepemilikan asing atau domestik. Di dalam pengelolaan perusahaan, persentase kepemilikan asing atau domestik yang lebih tinggi di suatu bank sama-sama menginginkan return yang lebih tinggi, oleh karenanya lebih menyukai aktivitas yang lebih berisiko. Charter value bank memberi manfaat dalam mendisiplinkan bank, untuk lebih berhati hati melakukan risk-taking dan mengontrol moral hazard. Charter value yang semakin tinggi juga dipandang investor memberikan return yang lebih tinggi, sehingga fluktuasi nilai di dalam pergerakan saham juga meningkat. Charter value bank yang semakin tinggi dengan kepemilikan asing lebih tinggi memberikan manfaat regulasi, yaitu lebih mendisiplinkan risk-taking mereka. Sementara charter value pada bank dengan kepemilikan domestik lebih tinggi mengakibatkan mereka terlibat dalam risk taking lebih tinggi, namun pada kondisi pasar tidak mempengaruhi risiko sistematis dan VaR. Pengukuran risiko berdasarkan data akuntansi akan memberikan hasil uji yang lebih konsisten dibandingkan pengukuran risiko berdsarkan data pasar. Data internal perusahaan atau data akuntansi lebih mampu menggambarkan pengambilan risiko yang dilakukan manajemen bank. Banyak komponen pasar yang tidak mampu ditangkap untuk lebih menjelaskan risk-taking bank. Oleh karena itu, pengukuran risiko berdasarkan data pasar saham memberikan hasil uji yang tidak konsisten.

Penelitian ini hanya menguji proksi variabel corporate governance yang mencakup beberapa fungsi pengawasan. Proksi untuk charter value menggunakan satu proksi saja, yaitu berdasarkan nilai pasar, oleh karena itu 
hanya dapat digunakan pada bank yang listed saja. Pengujian pengaruh charter value hanya menggunakan regresi linier sehingga tidak dapat diketahui nilai charter maksimum yang dapat mendeteksi bank akan meningkatkan pengambilan risiko, hal ini memberi manfaat bagi regulasi. Penelitian ini juga memiliki keterbatasan dalam hal pemilihan pengukuran risiko mana yang lebih menjelaskan perilaku pengambilan risiko yang dilakukan manajemen bank. Bagi penelitian selanjutnya, akan lebih baik untuk menambah proksi risiko yang lebih menjelaskan pengambilan risiko perbankan.

Sampel yang digunakan dalam penelitian ini hanya bank-bank yang terdaftar di BEI dan terbatas pada dua tipe kepemilikan saja. Studi selanjutnya akan memberikan banyak informasi lagi jika menggunakan bank-bank yang tidak terdaftar di BEI saja, namun bankbank yang memiliki izin operasi dari Bank Indonesia dan membagi tipe kepemilikan ke dalam beberapa karakteristik lain, seperti bank pemerintah atau bank pembagunan daerah, atau mengelompokkan bank berdasarkan karakteristik usaha, seperti bank perkreditan rakyat, bank syariah, atau bank konvensional.

\section{DAFTAR PUSTAKA}

Acharya, S., 1996. Charter Value, Minimum Bank Capital Requirement and Deposit Insurance Pricing in Equilibrium. Journal of Banking and Finance 20, 351-375.

Adams, R. B., Mehran, H., 2005. Corporate Governance, Board Structure, and Its Determinants in the Banking Industry. Working Paper, Federal Reserve Bank of New York.

Aebi, V., Sabato, G., Schimid, M., 2012. Risk Management, Corporate Governance, and Bank Performance in the Financial Crisis. Journal of Banking and Finance 36, 3213-3226.

Anderson, C.W., Campbell II, T. L., 2004. Corporate Governance of Japanese Banks. Journal of Corporate governance 10, 327-354.

Andres, P., Vallelado, E., 2008. Corporate Governance in Banking: The Role of
The Board of Directors. Journal of Banking and Finance 32, 2570-2580.

Bank Indonesia, 2013. Direktori Perbankan Indonesia 2013 Volume 14, Desember 2013. Departemen Perizinan dan Informasi Perbankan: Bank Indonesia.

Boubakri, N., Cosset, J. C., Saffar, W., 2013. The Role of State and Foreign Owners in Corporate Risk-Taking: Evidence from Privatization. Journal of Financial Economics 108, 641-658.

Boyd, J. H., Runkle, D. H., 2005. The Theory of Bank Pengambilan risiko and Competition Revisited. Journal of Finance 60, 1329-1343.

Caprio, G., Laeven, L., Levine, R., 2007. Governance and Bank Valuation. Journal of Financial Intermediation $16,584-617$.

Cebenoyan, S. A., Cooperman, S. E., Register, A. C., 1999. Ownership Structure, Charter Value, and Risk-Taking Behavior for Thrifts. Financial Management, Vol 28, No. 1, 43-60.

Chen, S. H., Liao, C. C., 2011. Are Foreign Bank More Profitable than Domestic Banks? Home- and Host-Country of Banking Market Structure, Governance, and Supervision. Journal of Banking and Finance 35, 819-839.

Furfine, C. H., 2001. Bank as monitors of other banks: Evidence from The Overnight Federal Funds Market. Journal of Business74, 33 -57.

Gonzales, F., 2005. Bank Regulation and RiskTaking Incentives: An International Comparison of Bank Risk. Journal of Banking and Finance 29, 1153-1184

Gosh, C., 2009. Charter Value and Pengambilan risiko Incentives: Evidence from Indian Banks. Journal of The Asia Pacific Economy 14, 270-286.

Greuning, H. van, Bratanovic, S. B., 2011. Analyzing Bank Risk. The International Bank for Reconstruction and Development/World Bank $3^{\text {th }}$ Edition. 
Hellman, T. F., Murdock, K. C., Stiglitz, J. E., 2000. Liberalization, Moral Hazard in Banking, and Prudential Regulation: Are Capital Requirements Enough? American Economic Review 90, 147165.

Iannotta, G., Nocera, G., Sironi, A., 2013. The Impact of Government Ownership on Bank Risk. Journal of Financial Intermediation 22, 152-176.

Keeley, M. C., 1990. Deposit Insurance, Risk, and Market Power in Banking. American Economic Review 80, 1183-1200.

Laeven, L., Levine, R., 2009. Bank Governance, Regulation, and Risk-Taking. Journal of Financial Economics 93, 259-275.

Marcus, A. J., 1984. Deregulation and Bank Financial Policy. Journal of Banking and Finance 8, 557-565.

Micco, A., Panizza, U., Yanez, M., 2007. Bank Ownership and Performance. Does Politics Matter? Journal of Banking Finance 31, 219-241.

Mierra, M. D., Repullo, R., 2010. Does Competition Reduce The Risk of Bank Failure? Review of Financial Studies 23, 3638-3664.

Morgan, D., 2002. Rating Banks: Risk and Uncertainty in a Opaque Industry. American Economic Review 92, 874888.

Mulbert, P. O., 2009. Corporate Governance of Banks. European Business Law Review 10, 411-436.
Nguyen, P. (a), 2011. Corporate Governance and Risk-Taking: Evidence from Japanese Firms. Pacific-Basin Journal 19, 278-297.

Nguyen, P. (b), 2012. The Impact of Foreign Investors on the Risk-Taking of Japanese Firms. Journal of The Japanese and International Economics 26, 233248.

Niu, J., 2012. An Analysis of The Relation between Bank Charter Value and RiskTaking. The Quarterly Review of Economics and Finance 52, 298-304.

Pathan, S., 2009. Strong Boards, CEO Power, and Bank Risk-Taking. Journal of Banking and Finance 33, 1340-1350.

Repullo, R., 2004. Capital Requirements, Market Power, and Risk-Taking in Banking. Journal of Financial Intermediation 13, 156-182.

Saunders, A., Strock, E., Travlos, N. G., 1990. Ownership Structure, Deregulation, Bank Risk-Taking. Journal of Finance 45, 643-365.

Saunders, A., Wilson, B., 2001. An Analysis of Bank Charter Value and Its Risk Constraining Incentives. Journal of Financial Services Research 19, 185-195.

Tandelilin, E., Kaaro, H., Mahadwartha, P. A., 2007. Corporate Governance, Risk Management, and Bank Performance: Does Type of Ownership Matter? EADN Working Paper 34. 


\section{Lampiran}

Tabel 3. Hasil Regresi Pengaruh Jumlah Komisaris terhadap Pengambilan Risiko

\begin{tabular}{|c|c|c|c|c|c|c|c|c|}
\hline \multirow{3}{*}{$\begin{array}{l}\text { V.Indepen- } \\
\text { den }\end{array}$} & \multicolumn{8}{|c|}{ Variabel Dependen } \\
\hline & \multicolumn{2}{|c|}{$\begin{array}{l}\text { Risiko Insolvency } \\
\text { (Z-score) }\end{array}$} & \multicolumn{2}{|c|}{$\begin{array}{l}\text { Risiko Sistematis } \\
\left(\beta^{2} \sigma_{\mathrm{m}}^{2}\right)\end{array}$} & \multicolumn{2}{|c|}{$\begin{array}{c}\text { Risiko Spesifik } \\
\left(\sigma^{2} \mathrm{e}_{\mathrm{it}}\right)\end{array}$} & \multicolumn{2}{|c|}{ VaR } \\
\hline & (1) & (2) & (3) & (4) & (5) & (6) & (7) & (8) \\
\hline $\begin{array}{l}\text { Komisaris } \\
\text { (t-stat) } \\
\text { (prob.) }\end{array}$ & $\begin{array}{l}0,039^{*} \\
(1,696) \\
(0,091)\end{array}$ & $\begin{array}{l}0,054 * * * \\
(2,531) \\
(0,012)\end{array}$ & $\begin{array}{l}-0,0004 * * \\
(-2,404) \\
(0,017)\end{array}$ & $\begin{array}{l}-0,0006 \text { *** } \\
(-2,792) \\
(0,005)\end{array}$ & $\begin{array}{l}-0,0002 * * * \\
(-4,175) \\
(0,000)\end{array}$ & $\begin{array}{l}-0,0002 * * * \\
(-5,095) \\
(0,000)\end{array}$ & $\begin{array}{l}-0,078 \\
(-1,116) \\
(0,265)\end{array}$ & $\begin{array}{l}-0,103 \\
(-1,370) \\
(0,172)\end{array}$ \\
\hline $\begin{array}{l}N P L \\
\text { (t-stat) } \\
\text { (prob.) }\end{array}$ & & $\begin{array}{l}-3,446 \text { *** } \\
(-2,661) \\
(0,008)\end{array}$ & & $\begin{array}{l}0,036 \text { *** } \\
(2,589) \\
(0,011)\end{array}$ & & $\begin{array}{l}0,002 \\
(0,585) \\
(0,558)\end{array}$ & & $\begin{array}{l}-1,382 \\
(-0,868) \\
(0,386)\end{array}$ \\
\hline $\begin{array}{l}L D R \\
\text { (t-stat) } \\
\text { (prob.) }\end{array}$ & & $\begin{array}{l}-0,906 \text { *** } \\
(-3,279) \\
(0,001)\end{array}$ & & $\begin{array}{l}0,001 \\
(0,473) \\
(0,637)\end{array}$ & & $\begin{array}{l}0,0006 \\
(1,164) \\
(0,245)\end{array}$ & & $\begin{array}{l}-1,222^{* *} \\
(-2,092) \\
(0,037)\end{array}$ \\
\hline $\begin{array}{l}C I \\
\text { (t-stat) } \\
\text { (prob.) }\end{array}$ & & $\begin{array}{l}-0,600 \text { *** } \\
(-2,751) \\
(0,006)\end{array}$ & & $\begin{array}{l}-0,001 * * \\
(-2,013) \\
(0,046)\end{array}$ & & $\begin{array}{l}0,0000 \\
(0,311) \\
(0,756) \\
\end{array}$ & & $\begin{array}{l}0,050 \\
(0,502) \\
(0,616) \\
\end{array}$ \\
\hline $\begin{array}{l}\text { Konstanta } \\
\text { (t-stat) } \\
\text { (prob.) }\end{array}$ & $\begin{array}{l}4,707 * * * \\
(38,871) \\
(0,000)\end{array}$ & $\begin{array}{l}5,897^{* * * *} \\
(26,206) \\
(0,000)\end{array}$ & $\begin{array}{l}0,004 \text { **** } \\
(3,671) \\
(0,000)\end{array}$ & $\begin{array}{l}0,004 * * \\
(1,967) \\
(0,051)\end{array}$ & $\begin{array}{l}0,002 * * * \\
(8,676) \\
(0,000)\end{array}$ & $\begin{array}{l}0,002 * * * \\
(4,284) \\
(0,000)\end{array}$ & $\begin{array}{l}1,265^{* * *} \\
(3,489) \\
(0,000)\end{array}$ & $\begin{array}{l}2,315^{\text {**** }} \\
3,563 \\
(0,000)\end{array}$ \\
\hline $\mathrm{R}^{2}$ & 0,005 & 0,100 & 0,030 & 0,058 & 0,091 & 0,0893 & 0,469 & 0,463 \\
\hline $\begin{array}{l}\text { F-statistik } \\
\text { Prob.F- } \\
\text { statistik }\end{array}$ & $\begin{array}{l}2,877^{*} \\
0,091\end{array}$ & $\begin{array}{l}9,828^{* * * *} \\
0,000\end{array}$ & $\begin{array}{l}5,780^{* *} \\
0,017\end{array}$ & $\begin{array}{l}3,294 * * * \\
0,012\end{array}$ & $\begin{array}{l}26,783^{* * *} \\
0,000\end{array}$ & $\begin{array}{l}6,978^{* * * *} \\
0,000\end{array}$ & $\begin{array}{l}7,269^{* * *} \\
0,000\end{array}$ & $\begin{array}{l}6,781^{\text {**** }} \\
0,000\end{array}$ \\
\hline $\begin{array}{l}\text { Jumlah } \\
\text { Observasi }\end{array}$ & 347 & 318 & 155 & 150 & 259 & 245 & 263 & 249 \\
\hline $\begin{array}{l}\text { Jumlah } \\
\text { Bank }\end{array}$ & 38 & 38 & 36 & 36 & 36 & 36 & 36 & 36 \\
\hline
\end{tabular}

Data di atas merupakan hasil regresi dari estimasi persamaan (2). Kolom (1), (3), (5), dan (7) merupakan regresi pengaruh jumlah komisaris terhadap risiko tanpa variabel kontrol. Kolom (2), (4), (6), dan (8) merupakan regresi pengaruh jumlah komisaris terhadap risiko dengan variabel kontrol. Variabel dependen Z-score diperoleh dari penjumlahan ROA dan CAR dibagi deviasi standar ROA. Risiko sistematis dan risiko spesifik diperoleh dari regresi SIM, menggunakan return saham harian. VaR adalah Value at Risk yang dihitung dengan tingkat signifikansi 5\%, menggunakan metode historic or back simulation dari return saham harian.

$*, * *, * *$, berturut-turut signifikan pada $10 \%, 5 \%$, dan $1 \%$.

Tabel 4.5. Hasil Regresi Pengaruh Persentase Komisaris Independen terhadap Pengambilan Risiko

\begin{tabular}{|c|c|c|c|c|c|c|c|c|}
\hline \multirow{3}{*}{$\begin{array}{l}\text { V.Indepen- } \\
\text { den }\end{array}$} & \multicolumn{8}{|c|}{ Variabel Dependen } \\
\hline & \multicolumn{2}{|c|}{$\begin{array}{c}\text { Risiko Insolvency } \\
\text { (Z-score })\end{array}$} & \multicolumn{2}{|c|}{$\begin{array}{c}\text { Risiko Sistematis } \\
\left(\beta^{2} \sigma_{\mathrm{m}}{ }^{2}\right)\end{array}$} & \multicolumn{2}{|c|}{$\begin{array}{c}\text { Risiko Spesifik } \\
\left(\sigma^{2} \mathrm{e}_{i t}\right)\end{array}$} & \multicolumn{2}{|c|}{ VaR } \\
\hline & (1) & (2) & (3) & (4) & (5) & (6) & (7) & (8) \\
\hline $\begin{array}{l}\text { Kom_Indp } \\
\text { (t-stat) } \\
\text { (prob.) }\end{array}$ & $\begin{array}{l}0,208 \\
(0,890) \\
(0,373)\end{array}$ & $\begin{array}{l}0,109 \\
(0,650) \\
(0,516)\end{array}$ & $\begin{array}{l}-0,005^{* * *} \\
(-8,157) \\
(0,000)\end{array}$ & $\begin{array}{l}-0,005^{* * *} \\
(-7,946) \\
(0,000)\end{array}$ & $\begin{array}{l}-0,004 * * * \\
(-2,619) \\
(0,009)\end{array}$ & $\begin{array}{l}-0,001 * * \\
(-2,318) \\
(0,021)\end{array}$ & $\begin{array}{l}-0,320 \\
(-0,925) \\
(0,355)\end{array}$ & $\begin{array}{l}-0,131 \\
(-0,350) \\
(0,726)\end{array}$ \\
\hline $\begin{array}{l}N P L \\
\text { (t-stat) } \\
\text { (prob.) }\end{array}$ & & $\begin{array}{l}-3,037 * * \\
(-2,303) \\
(0,021)\end{array}$ & & $\begin{array}{l}0,007 * * \\
(2,345) \\
(0,020)\end{array}$ & & $\begin{array}{l}-0,002 \\
(-0,834) \\
(0,404)\end{array}$ & & $\begin{array}{l}-1,484 \\
(-0,969) \\
(0,333)\end{array}$ \\
\hline $\begin{array}{l}L D R \\
\text { (t-stat) } \\
\text { (prob.) }\end{array}$ & & $\begin{array}{l}-0,779 * * * \\
(-2,859) \\
(0,004)\end{array}$ & & $\begin{array}{l}0,0002 \\
(0,770) \\
(0,442)\end{array}$ & & $\begin{array}{l}0,0008^{*} \\
(2,193) \\
(0,029)\end{array}$ & & $\begin{array}{l}-0,966^{*} \\
(-1,784) \\
(0,075)\end{array}$ \\
\hline $\begin{array}{l}\text { CI } \\
\text { (t-stat) } \\
\text { (prob.) }\end{array}$ & & $\begin{array}{l}-0.691 * * \\
(-2,246) \\
(0,025)\end{array}$ & & $\begin{array}{l}0,002 * * * \\
(4,881) \\
(0,000)\end{array}$ & & $\begin{array}{l}0,003 * * * \\
(4,416) \\
(0,000)\end{array}$ & & $\begin{array}{l}0,0424 \\
(0,421) \\
(0,673)\end{array}$ \\
\hline $\begin{array}{l}\text { Konstanta } \\
\text { (t-stat.) } \\
\text { (prob.) }\end{array}$ & $\begin{array}{l}4,793 * * * \\
(35,652) \\
(0,000)\end{array}$ & $\begin{array}{l}6,079 * * * \\
(20,303) \\
(0,000)\end{array}$ & $\begin{array}{l}0,003 * * * \\
(9,257) \\
(0,000)\end{array}$ & $\begin{array}{l}0,0009 \\
(1,531) \\
(0,127)\end{array}$ & $\begin{array}{l}0,004 * * * \\
(4,131) \\
(0,000)\end{array}$ & $\begin{array}{l}-0,001 * * * \\
(-3,044) \\
(0,002)\end{array}$ & $\begin{array}{l}0,987 * * * \\
(4,074) \\
(0,000)\end{array}$ & $\begin{array}{l}1,641 * * * \\
(3,831) \\
(0,0002)\end{array}$ \\
\hline $\mathrm{R}^{2}$ & 0,002 & 0,058 & 0,298 & 0,830 & 0,023 & 0,147 & 0,003 & 0,002 \\
\hline $\begin{array}{l}\text { F-statistik } \\
\text { Prob.F- } \\
\text { statistik }\end{array}$ & $\begin{array}{l}0,786^{* * *} \\
0,000\end{array}$ & $\begin{array}{l}5,904 * * * \\
0,000\end{array}$ & $\begin{array}{l}66,539 * * * \\
0,000\end{array}$ & $\begin{array}{l}182,73 * * * \\
0,000\end{array}$ & $\begin{array}{l}7,105 * * * \\
0,008\end{array}$ & $\begin{array}{l}11,50^{* *} \\
0,015\end{array}$ & $\begin{array}{l}0,874 \\
0,350\end{array}$ & $\begin{array}{l}1,139 \\
0,338\end{array}$ \\
\hline $\begin{array}{l}\text { Jumlah } \\
\text { Observasi }\end{array}$ & 345 & 317 & 155 & 149 & 258 & 244 & 262 & 248 \\
\hline $\begin{array}{l}\text { Jumlah } \\
\text { Bank }\end{array}$ & 38 & 38 & 36 & 36 & 36 & 36 & 36 & 36 \\
\hline
\end{tabular}

Data di atas merupakan hasil regresi dari estimasi persamaan (2). Kolom (1), (3), (5), dan (7) merupakan regresi pengaruh komisaris independen terhadap risiko tanpa variabel kontrol. Kolom (2), (4), (6), dan (8) merupakan regresi pengaruh komisaris independen terhadap risiko dengan variabel kontrol. Komp_Indp merupakan persentase komisaris independen di bank. Variabel dependen Z-score diperoleh dari penjumlahan ROA dan CAR dibagi deviasi standar ROA. Risiko sistematis dan risiko spesifik diperoleh dari regresi SIM, menggunakan return saham harian. VaR adalah Value at Risk yang dihitung dengan tingkat signifikansi 5\%, menggunakan metode historic or back simulation dari return saham harian.

$*, * * * * *$, berturut-turut signifikan pada $10 \%, 5 \%$, dan $1 \%$. 
Tabel 5. Hasil Regresi Pengaruh Kualitas Manajemen Risiko terhadap Pengambilan Risiko

\begin{tabular}{|c|c|c|c|c|c|c|c|c|}
\hline \multirow{3}{*}{$\begin{array}{c}\text { V.Indepen } \\
\text { den }\end{array}$} & \multicolumn{8}{|c|}{ Variabel Dependen } \\
\hline & \multicolumn{2}{|c|}{$\begin{array}{c}\text { Risiko Insolvency (Z- } \\
\text { score) }\end{array}$} & \multicolumn{2}{|c|}{$\begin{array}{c}\text { Risiko Sistematis } \\
\left(\beta^{2} \sigma_{\mathrm{m}}^{2}\right)\end{array}$} & \multicolumn{2}{|c|}{$\begin{array}{c}\text { Risiko Spesifik } \\
\left(\sigma^{2} \mathrm{e}_{i \mathrm{it}}\right)\end{array}$} & \multicolumn{2}{|c|}{ VaR } \\
\hline & (1) & $(2)$ & (3) & (4) & (5) & (6) & (7) & (8) \\
\hline $\begin{array}{l}\text { Kualitas } \\
\text { (t-stat) } \\
\text { (prob.) }\end{array}$ & $\begin{array}{l}0,014 * * * \\
(2,459) \\
(0,014)\end{array}$ & $\begin{array}{l}0,045 \\
(0,688) \\
(0,504)\end{array}$ & $\begin{array}{l}-0,0002 * * * \\
(-4,423) \\
(0,000)\end{array}$ & $\begin{array}{l}-0,0002 * * * \\
(-4,500) \\
(0,000)\end{array}$ & $\begin{array}{l}-0,0003^{* * *} \\
(-5,008) \\
(0,000)\end{array}$ & $\begin{array}{l}-0,0003^{* * *} \\
(-5,376) \\
(0,000)\end{array}$ & $\begin{array}{l}-0,213 * * \\
(-2,041) \\
(0,043)\end{array}$ & $\begin{array}{l}-0,292 * * \\
(-2,231) \\
(0,027)\end{array}$ \\
\hline $\begin{array}{l}N P L \\
\text { (t-stat) } \\
\text { (prob.) }\end{array}$ & & $\begin{array}{l}-2,893 \\
(-1,574) \\
(0,117)\end{array}$ & & $\begin{array}{l}0,007 * * * \\
(2,856) \\
(0,005)\end{array}$ & & $\begin{array}{l}-0,004 * * * \\
(-2,530) \\
(0,012)\end{array}$ & & $\begin{array}{l}-1,384 \\
(-0,636) \\
(0,528)\end{array}$ \\
\hline $\begin{array}{l}L D R \\
\text { (t-stat) } \\
\text { (prob.) }\end{array}$ & & $\begin{array}{l}-0,154 \\
(-0,392) \\
(0,695)\end{array}$ & & $\begin{array}{l}-0,001 * * \\
(-2,346) \\
(0,021)\end{array}$ & & $\begin{array}{l}-0,0005 \\
(-1,092) \\
(0,276)\end{array}$ & & $\begin{array}{l}0,309 \\
(0,275) \\
(0,783)\end{array}$ \\
\hline $\begin{array}{l}C I \\
\text { (t-stat) } \\
\text { (prob.) }\end{array}$ & & $\begin{array}{c}-1,013 * \\
(-1,800) \\
(0,073)\end{array}$ & & $\begin{array}{l}-0,001 * * \\
(-2,414) \\
(0,017)\end{array}$ & & $\begin{array}{l}0,001 * * * \\
(2,592) \\
(0,010)\end{array}$ & & $\begin{array}{l}0,248 \\
(0,329) \\
(0,742)\end{array}$ \\
\hline $\begin{array}{l}\text { Konstanta } \\
\text { (t-stat.) } \\
\text { (prob.) }\end{array}$ & $\begin{array}{l}4,743 * * * \\
(39,207) \\
(0,000)\end{array}$ & $\begin{array}{l}5,924 * * * \\
(10,967) \\
(0,000)\end{array}$ & $\begin{array}{l}0,001 * * * \\
8,404 \\
(0,000)\end{array}$ & $\begin{array}{l}0,002 * * * \\
(5,448) \\
(0,000)\end{array}$ & $\begin{array}{l}0,0016^{* * * *} \\
(9,859) \\
(0,000)\end{array}$ & $\begin{array}{l}0,001^{*} \\
(1,885) \\
(0,061)\end{array}$ & $\begin{array}{l}1,289 * * * \\
(6,107) \\
(0,000)\end{array}$ & $\begin{array}{l}1,021 \\
(1,168) \\
(0,244) \\
\end{array}$ \\
\hline $\mathrm{R}^{2}$ & 0,028 & 0,0449 & 0,155 & 0,348 & 0,121 & 0,146 & 0,466 & 0,447 \\
\hline $\begin{array}{l}\text { F-statistik } \\
\text { Prob.F- } \\
\text { statistik }\end{array}$ & $\begin{array}{l}6,051^{* * *} \\
0,014\end{array}$ & $\begin{array}{l}2,847 * * * \\
0,025\end{array}$ & $\begin{array}{l}19,563 * * * \\
0,000\end{array}$ & $\begin{array}{l}13,708 * * * \\
0,000\end{array}$ & $\begin{array}{l}25,082 * * * \\
0,000\end{array}$ & $\begin{array}{l}7,863^{* * *} \\
0,000\end{array}$ & $\begin{array}{l}5,425 * * * \\
0,000\end{array}$ & $\begin{array}{l}4,779 * * * \\
0,000\end{array}$ \\
\hline $\begin{array}{l}\text { Jumlah } \\
\text { Observasi }\end{array}$ & 174 & 158 & 102 & 97 & 175 & 162 & 178 & 165 \\
\hline $\begin{array}{l}\text { Jumlah } \\
\text { Bank }\end{array}$ & 38 & 38 & 36 & 36 & 36 & 36 & 36 & 36 \\
\hline
\end{tabular}

Data di atas merupakan hasil regresi dari estimasi persamaan (2). Kolom (1), (3), (5), dan (7) merupakan regresi pengaruh kualitas manjemen risiko terhadap risiko tanpa variabel kontrol. Kolom (2), (4), (6), dan (8) merupakan regresi pengaruh kualitas manajemen risiko terhadap risiko dengan variabel kontrol. Kualitas manajemen risiko merupakan jumlah anggota pemantau risiko dikalikan dengan masa kerjanya. Variabel dependen Z-score diperoleh dari penjumlahan ROA dan CAR dibagi deviasi standar ROA. Risiko sistematis dan risiko spesifik diperoleh dari regresi SIM, menggunakan return saham harian. VaR adalah Value at Risk yang dihitung dengan tingkat signifikansi 5\%, menggunakan metode historic or back simulation dari return saham harian.

$*, * * * * *$, berturut-turut signifikan pada $10 \%, 5 \%$, dan $1 \%$

Tabel 6. Hasil Regresi Pengaruh Jumlah Rapat Komisaris dan Direksi terhadap Pengambilan Risiko

\begin{tabular}{|c|c|c|c|c|c|c|c|c|}
\hline \multirow{3}{*}{$\begin{array}{l}\text { V.Indepen } \\
\text { den }\end{array}$} & \multicolumn{8}{|c|}{ Variabel Dependen } \\
\hline & \multicolumn{2}{|c|}{$\begin{array}{c}\text { Risiko Insolvency } \\
\text { (Z-score })\end{array}$} & \multicolumn{2}{|c|}{$\begin{array}{c}\text { Risiko Sistematis } \\
\left(\beta^{2} \sigma_{\mathrm{m}}{ }^{2}\right)\end{array}$} & \multicolumn{2}{|c|}{$\begin{array}{c}\text { Risiko Spesifik } \\
\left(\sigma^{2} \mathrm{e}_{i t}\right)\end{array}$} & \multicolumn{2}{|c|}{ VaR } \\
\hline & (1) & (2) & (3) & (4) & (5) & (6) & (7) & (8) \\
\hline $\begin{array}{l}\text { Rapat } \\
\text { (t-stat) } \\
\text { (prob.) }\end{array}$ & $\begin{array}{l}-0,031 \\
(-0,395) \\
(0,692)\end{array}$ & $\begin{array}{l}0,109 \\
(0,958) \\
(0,340)\end{array}$ & $\begin{array}{l}-0,00002 \\
(-0,119) \\
(0,905)\end{array}$ & $\begin{array}{l}-0,00002 \\
(-0,932) \\
(0,355)\end{array}$ & $\begin{array}{l}-0,0002 \text { *** } \\
(-2,917) \\
(0,004)\end{array}$ & $\begin{array}{l}-0,0002 * * * * \\
(-2,630) \\
(0,009)\end{array}$ & $\begin{array}{l}0,036 \\
(0,437) \\
(0,662)\end{array}$ & $\begin{array}{l}-0,004 \\
(-0,045) \\
(0,964)\end{array}$ \\
\hline $\begin{array}{l}N P L \\
\text { (t-stat) } \\
\text { (prob.) }\end{array}$ & & $\begin{array}{l}-4,704 \\
(-1,617) \\
(0,108)\end{array}$ & & $\begin{array}{l}0,007 * * \\
(2,156) \\
(0,036)\end{array}$ & & $\begin{array}{l}-0,004^{*} \\
(-1,719) \\
(0,088)\end{array}$ & & $\begin{array}{l}1,663 \\
(0,607) \\
(0,544)\end{array}$ \\
\hline $\begin{array}{l}L D R \\
\text { (t-stat) } \\
\text { (prob.) }\end{array}$ & & $\begin{array}{l}-0,622 \\
(-0,932) \\
(0,353)\end{array}$ & & $\begin{array}{l}0,001 * \\
(1,615) \\
(0,112)\end{array}$ & & $\begin{array}{l}-0,0005 \\
(-1,544) \\
(0,125)\end{array}$ & & $\begin{array}{l}-1,577 * * * \\
(-4,997) \\
(0,000)\end{array}$ \\
\hline $\begin{array}{l}C I \\
\text { (t-stat) } \\
\text { (prob.) }\end{array}$ & & $\begin{array}{l}-0,1704 \\
(-0,281) \\
(0,779)\end{array}$ & & $\begin{array}{l}-0,001 * \\
(-1,883) \\
(0,065)\end{array}$ & & $\begin{array}{l}0,001 * * * \\
(2,929) \\
(0,004)\end{array}$ & & $\begin{array}{l}-1,637 \text { **** } \\
(-3,316) \\
(0,001)\end{array}$ \\
\hline $\begin{array}{l}\text { Konstanta } \\
\text { (t-stat.) } \\
\text { (prob.) }\end{array}$ & $\begin{array}{l}5,030 \text { *** } \\
(24,222) \\
(0,000)\end{array}$ & $\begin{array}{l}5,492 * * * \\
(7,230) \\
(0,000)\end{array}$ & $\begin{array}{l}0,0007 \\
(1,459) \\
(0,150)\end{array}$ & $\begin{array}{l}0,0007 \\
(0,833) \\
(0,408)\end{array}$ & $\begin{array}{l}0,001 \text { **** } \\
(5,716) \\
(0,000)\end{array}$ & $\begin{array}{l}0,0007 \\
(1,524) \\
(0,130)\end{array}$ & $\begin{array}{l}0,397 * * \\
(2,069) \\
(0,040)\end{array}$ & $\begin{array}{l}3,092 * * * * \\
(6,758) \\
(0,000)\end{array}$ \\
\hline $\mathrm{R}^{2}$ & 0,001 & 0,008 & 0,269 & 0,013 & 0,066 & 0,158 & 0,001 & 0,324 \\
\hline $\begin{array}{l}\text { F-statistik } \\
\text { Prob.F- } \\
\text { statistik }\end{array}$ & $\begin{array}{l}0,156 \\
0,692\end{array}$ & $\begin{array}{l}1,249 \\
0,249\end{array}$ & $\begin{array}{l}0,864 \\
0,640\end{array}$ & $\begin{array}{l}1,037 \\
0,443\end{array}$ & $\begin{array}{l}8,513 * * * \\
0,004\end{array}$ & $\begin{array}{l}6,354 * * * \\
0,000\end{array}$ & $\begin{array}{l}0,191 \\
0,662\end{array}$ & $\begin{array}{l}14,807 \text { *** } \\
0,000\end{array}$ \\
\hline $\begin{array}{l}\text { Jumlah } \\
\text { Observasi }\end{array}$ & 123 & 116 & 78 & 75 & 121 & 115 & 122 & 116 \\
\hline $\begin{array}{l}\text { Jumlah } \\
\text { Bank }\end{array}$ & 38 & 38 & 36 & 36 & 36 & 36 & 36 & 36 \\
\hline
\end{tabular}

Dank di atas merupakan hasil regresi dari estimasi persamaan (2). Kolom (1), (3), (5), dan (7) merupakan regresi pengaruh kualitas manjemen risiko terhadap risiko tanpa variabel kontrol. Kolom (2), (4), (6), dan (8) merupakan regresi pengaruh rapat gabungan terhadap risiko dengan variabel kontrol. Rapat gabungan merupakan jumlah pertemuan komisaris dan direksi selama satu tahun. Variabel dependen Z-score diperoleh dari penjumlahan ROA dan CAR dibagi deviasi standar ROA. Risiko sistematis dan risiko spesifik diperoleh dari regresi SIM, menggunakan return saham harian. VaR adalah Value at Risk yang dihitung dengan tingkat signifikansi 5\%, menggunakan metode historic or back simulation dari retum saham harian.

$*, * *, * * *$, berturut-turut signifikan pada $10 \%, 5 \%$, dan $1 \%$ 
Tabel 7. Regresi Interaksi Jumlah Komisaris dan Kepemilikan Asing terhadap Pengambilan Risiko

\begin{tabular}{|c|c|c|c|c|c|c|c|c|}
\hline \multirow{3}{*}{$\begin{array}{c}\text { V.Indepen- } \\
\text { den }\end{array}$} & \multicolumn{8}{|c|}{ Variabel Dependen } \\
\hline & \multicolumn{2}{|c|}{$\begin{array}{c}\text { Risiko Insolvency } \\
(\text { Z-score })\end{array}$} & \multicolumn{2}{|c|}{$\begin{array}{c}\text { Risiko Sistematis } \\
\left(\beta^{2} \sigma_{\mathrm{m}}{ }^{2}\right)\end{array}$} & \multicolumn{2}{|c|}{$\begin{array}{c}\text { Risiko Spesifik } \\
\left(\sigma^{2} e_{i t}\right)\end{array}$} & \multicolumn{2}{|c|}{ VaR } \\
\hline & (1) & (2) & (3) & (4) & (5) & (6) & (7) & (8) \\
\hline $\begin{array}{l}\text { Komisaris } \\
\text { (t-stat) } \\
\text { (prob.) }\end{array}$ & $\begin{array}{l}-0,376 \\
(-0,529) \\
(0,598)\end{array}$ & $\begin{array}{l}0,133 \\
(0,173) \\
(0,862)\end{array}$ & $\begin{array}{l}-0,001 \\
(-1,547) \\
(0,130)\end{array}$ & $\begin{array}{l}-0,0007 \\
(-0,734) \\
(0,467)\end{array}$ & $\begin{array}{l}-0,002 \\
(-1,321) \\
(0,190)\end{array}$ & $\begin{array}{l}-0,002 \\
(-1,153) \\
(0,252)\end{array}$ & $\begin{array}{l}0,819^{*} \\
(1,883) \\
(0,069)\end{array}$ & $\begin{array}{l}0,702 \\
(1,508) \\
(0,135)\end{array}$ \\
\hline $\begin{array}{l}\text { FO } \\
\text { (t-stat) } \\
\text { (prob.) }\end{array}$ & $\begin{array}{l}0,056 \\
(0,038) \\
(0,969)\end{array}$ & $\begin{array}{l}0,752 \\
(0,398) \\
(0,691)\end{array}$ & $\begin{array}{l}-0,007 * * \\
(-2,490) \\
(0,017)\end{array}$ & $\begin{array}{l}-0,004^{*} \\
(-1,723) \\
(0,093)\end{array}$ & $\begin{array}{l}-0,005^{*} \\
(-1,715) \\
(0,090)\end{array}$ & $\begin{array}{l}-0,006 \\
(-1,143) \\
(0,256)\end{array}$ & $\begin{array}{l}1,549^{*} \\
(1,640) \\
(0,104)\end{array}$ & $\begin{array}{l}0,957 \\
(1,197) \\
(0,235)\end{array}$ \\
\hline $\begin{array}{l}\text { Kom*FO } \\
\text { (t-stat) } \\
\text { (prob.) }\end{array}$ & $\begin{array}{l}0,285 \\
(0,299) \\
(0,765)\end{array}$ & $\begin{array}{l}-0,174 \\
(-0,152) \\
(0,879)\end{array}$ & $\begin{array}{l}0,002 * \\
(1,741) \\
(0,089)\end{array}$ & $\begin{array}{l}0,001 \\
(1,102) \\
(0,277)\end{array}$ & $\begin{array}{l}0,0017 \\
(0,881) \\
(0,380)\end{array}$ & $\begin{array}{l}0,003 \\
(0,954) \\
(0,922)\end{array}$ & $\begin{array}{l}-0,798 \\
(-1,286) \\
(0,201)\end{array}$ & \begin{tabular}{|l|}
$-0,412$ \\
$(-0,643)$ \\
$(0,521)$
\end{tabular} \\
\hline $\begin{array}{l}N P L \\
\text { (t-stat) } \\
\text { (prob.) }\end{array}$ & & $\begin{array}{l}-5,908 \\
(-1,077) \\
(0,285)\end{array}$ & & $\begin{array}{l}0,004 \\
(0,546) \\
(0,587)\end{array}$ & & $\begin{array}{l}0,001 \\
(0,097) \\
(0,922)\end{array}$ & & $\begin{array}{l}3,395 \\
(1,583) \\
(0,142)\end{array}$ \\
\hline $\begin{array}{l}L D R \\
\text { (t-stat) } \\
\text { (prob.) }\end{array}$ & & $\begin{array}{l}-1,231^{* *} \\
(-2,392) \\
(0,019)\end{array}$ & & $\begin{array}{l}-0,001 * * * \\
(-3,030) \\
(0,004)\end{array}$ & & $\begin{array}{l}-0,001 \\
(-1,018) \\
(0,311)\end{array}$ & & \begin{tabular}{|l|}
$-0,571^{*}$ \\
$(-1,918)$ \\
$(0,058)$
\end{tabular} \\
\hline $\begin{array}{l}C I \\
\text { (t-stat) } \\
\text { (prob.) }\end{array}$ & & $\begin{array}{l}-3,241^{\text {**** }} \\
(-3,828) \\
(0,000)\end{array}$ & & $\begin{array}{l}0,0004 \\
(0,690) \\
(0,494)\end{array}$ & & $\begin{array}{l}-0,0008 \\
(0,552) \\
(0,582)\end{array}$ & & \begin{tabular}{|l|}
$-0,633^{*}$ \\
$(-1,899)$ \\
$(0,061)$
\end{tabular} \\
\hline $\begin{array}{l}\text { Konstanta } \\
\text { (t-stat.) } \\
\text { (prob.) }\end{array}$ & $\begin{array}{l}5,298 * * * \\
(4,951) \\
(0,000)\end{array}$ & $\begin{array}{l}8,328 * * * \\
(5,400) \\
(0,000)\end{array}$ & $\begin{array}{l}0,005 \text { *** } \\
(2,695) \\
(0,010)\end{array}$ & $\begin{array}{l}0,003 * \\
(1,734) \\
(0.091)\end{array}$ & $\begin{array}{l}0,006 \text { *** } \\
(2,606) \\
(0,010)\end{array}$ & $\begin{array}{l}0,006 \\
(1,405) \\
(0,164)\end{array}$ & \begin{tabular}{|l|}
$-1,133^{*}$ \\
$(-1,842)$ \\
$(0,063)$
\end{tabular} & \begin{tabular}{|l|}
$-0,106$ \\
$(-0,193)$ \\
$(0,847)$
\end{tabular} \\
\hline $\mathrm{R}^{2}$ & $-0,013$ & 0,247 & 0,361 & 0,585 & 0,208 & 0,024 & 0,121 & 0,095 \\
\hline F-statistik & 0,641 & $5,008 * * *$ & 8,742 *** & $10,656^{* * * *}$ & $8,441^{* * *}$ & 1,330 & $4,933^{*} * * *$ & 3,970 *** \\
\hline $\begin{array}{l}\text { Prob.F- } \\
\text { statistik }\end{array}$ & 0,590 & 0,000 & 0,000 & 0,000 & 0,000 & 0,254 & 0,003 & 0,010 \\
\hline $\begin{array}{l}\text { Jumlah } \\
\text { Observasi }\end{array}$ & 80 & 74 & 42 & 42 & 86 & 81 & 86 & 85 \\
\hline Jumlah Bank & 13 & 13 & 10 & 10 & 13 & 13 & 13 & 13 \\
\hline
\end{tabular}

Data di atas merupakan hasil regresi dari estimasi persamaan (4). Kolom (1), (3), (5), dan (7) merupakan regresi interaksi pengaruh jumlah komisaris dan kepemilikan asing terhadap risiko tanpa variabel kontrol. Kolom (2), (4), (6), dan (8) merupakan regresi interaksi pengaruh jumlah komisaris dan kepemilikan asing terhadap risiko dengan variabel kontrol. FO merupakan proporsi kepemilikan asing sebagai ultimate shareholder di bank. Variabel dependen Z-score diperoleh dari penjumlahan ROA dan CAR dibagi deviasi standar ROA. Risiko sistematis dan risiko spesifik diperoleh dari regresi SIM, menggunakan return saham harian. VaR adalah Value at Risk yang dihitung dengan tingkat signifikansi 5\%, menggunakan metode historic or back simulation dari return saham harian.

$*, * *, * *$, berturut-turut signifikan pada $10 \%, 5 \%$, dan $1 \%$.

Tabel 8. Regresi Interaksi Persentase Komisaris Independen dan Kepemilikan Asing terhadap Pengambilan Risiko

\begin{tabular}{|c|c|c|c|c|c|c|c|c|}
\hline \multirow{3}{*}{ V.Independen } & \multicolumn{8}{|c|}{ Variabel Dependen } \\
\hline & \multicolumn{2}{|c|}{$\begin{array}{c}\text { Risiko Insolvency (Z- } \\
\text { score) }\end{array}$} & \multicolumn{2}{|c|}{$\begin{array}{l}\text { Risiko Sistematis } \\
\left(\beta^{2} \sigma_{m}^{2}\right)\end{array}$} & \multicolumn{2}{|c|}{$\begin{array}{l}\text { Risiko Spesifik } \\
\left(\sigma^{2} \mathrm{e}_{\mathrm{it}}\right)\end{array}$} & \multicolumn{2}{|l|}{ VaR } \\
\hline & (1) & (2) & (3) & (4) & (5) & (6) & (7) & (8) \\
\hline $\begin{array}{l}\text { Kom_Indp } \\
\text { (t-stat) } \\
\text { (prob.) }\end{array}$ & $\begin{array}{l}1,360 \\
(1,290) \\
(0,201)\end{array}$ & $\begin{array}{l}0,014 \\
(0,014) \\
(0,988) \\
\end{array}$ & $\begin{array}{l}-0,0006 \\
(-0,370) \\
(0,713)\end{array}$ & $\begin{array}{l}-0,002 * * \\
(-2,088) \\
(0,044)\end{array}$ & $\begin{array}{l}0,0002 \\
(0,155) \\
(0,877)\end{array}$ & $\begin{array}{l}0,00003 \\
(0,008) \\
(0,992)\end{array}$ & $\begin{array}{l}0,220 \\
(0,299) \\
(0,765)\end{array}$ & $\begin{array}{l}0,383 \\
(0,396) \\
(0,592)\end{array}$ \\
\hline $\begin{array}{l}\text { FO } \\
\text { (t-stat) } \\
\text { (prob.) }\end{array}$ & $\begin{array}{l}1,252^{*} \\
(1,618) \\
(0,109) \\
\end{array}$ & $\begin{array}{l}0,205 \\
(0,197) \\
(0,844) \\
\end{array}$ & $\begin{array}{l}-0,002^{* * *} \\
(-2,136) \\
(0,039) \\
\end{array}$ & $\begin{array}{l}-0,003^{* * * *} \\
(-4,164) \\
(0,000) \\
\end{array}$ & $\begin{array}{l}-0,003^{* *} \\
(-2,232) \\
(0,028) \\
\end{array}$ & $\begin{array}{l}-0,003 \\
(-0,918) \\
(0,361)\end{array}$ & $\begin{array}{l}1,711^{* *} \\
(2,403) \\
(0,018)\end{array}$ & $\begin{array}{l}1,246 \\
(1,488) \\
(0,140)\end{array}$ \\
\hline $\begin{array}{l}\text { Kom_Indp*FO } \\
\text { (t-stat) } \\
\text { (prob.) }\end{array}$ & $\begin{array}{l}-2,007 \\
(-1,216) \\
(0,227)\end{array}$ & $\begin{array}{l}0,706 \\
(0,349) \\
(0,727) \\
\end{array}$ & $\begin{array}{l}0,001 \\
(0,597) \\
(0,553)\end{array}$ & $\begin{array}{l}0,005^{* * *} \\
(2,539) \\
(0,015)\end{array}$ & $\begin{array}{l}0,0007 \\
(0,252) \\
(0,801)\end{array}$ & $\begin{array}{l}0,003 \\
(0,446) \\
(0,656)\end{array}$ & $\begin{array}{l}-2,247 \\
(-1,521) \\
(0,131)\end{array}$ & $\begin{array}{l}-1,638 \\
(-0,922) \\
(0,359)\end{array}$ \\
\hline $\begin{array}{l}N P L \\
\text { (t-stat) } \\
\text { (prob.) }\end{array}$ & & \begin{tabular}{|l|}
$-4,013$ \\
$(-0,743)$ \\
$(0,460)$ \\
\end{tabular} & & $\begin{array}{l}0,010 \\
(1,375) \\
(0,177) \\
\end{array}$ & & $\begin{array}{l}0,004 \\
(0,334) \\
(0,739) \\
\end{array}$ & & $\begin{array}{l}3,252 \\
(1,137) \\
(0,259) \\
\end{array}$ \\
\hline $\begin{array}{l}L D R \\
\text { (t-stat) } \\
\text { (prob.) }\end{array}$ & & $\begin{array}{l}-1,319^{* * * *} \\
(-2,712) \\
(0,008) \\
\end{array}$ & & $\begin{array}{l}-0,001^{* * * *} \\
(-3,096) \\
(0,003) \\
\end{array}$ & & $\begin{array}{l}-0,002^{*} \\
(-1,690) \\
(0,095)\end{array}$ & & $\begin{array}{l}-0,291 \\
(-0,621) \\
(0,536) \\
\end{array}$ \\
\hline $\begin{array}{l}\text { CI } \\
\text { (t-stat) } \\
\text { (prob.) }\end{array}$ & & $\begin{array}{l}-3,425 * * * \\
(-3,690) \\
(0,000)\end{array}$ & & $\begin{array}{l}0,0003 \\
(0,620) \\
(0,538)\end{array}$ & & $\begin{array}{l}0,0004 \\
(0,292) \\
(0,771)\end{array}$ & & $\begin{array}{l}-0,610 \\
(-1,561) \\
(0,122)\end{array}$ \\
\hline $\begin{array}{l}\text { Konstanta } \\
\text { (t-stat.) } \\
\text { (prob.) }\end{array}$ & $\begin{array}{l}4,200 \text { *** } \\
(8,211) \\
(0,000)\end{array}$ & $\begin{array}{l}8,653 \text { *** } \\
(7,334) \\
(0,000)\end{array}$ & $\begin{array}{l}0,002 * * * \\
(3,216) \\
(0,002)\end{array}$ & $\begin{array}{l}0,002^{* * * *} \\
(4,647) \\
(0,000)\end{array}$ & $\begin{array}{l}0,003 * * * \\
(4,167) \\
(0,000)\end{array}$ & $\begin{array}{l}0,003 \\
(1,212) \\
(0,229)\end{array}$ & $\begin{array}{l}-0,120 \\
(-0,343) \\
(0,732)\end{array}$ & $\begin{array}{l}0,558 \\
(0,920) \\
(0,360)\end{array}$ \\
\hline $\mathrm{R}^{2}$ & $-0,000$ & 0,261 & 0,285 & 0,722 & 0,194 & 0,020 & 0,095 & 0,072 \\
\hline $\begin{array}{l}\text { F-statistik } \\
\text { Prob.F-statistik }\end{array}$ & $\begin{array}{l}0,991 \\
0,401\end{array}$ & \begin{tabular}{|l}
$5,246^{* * * * *}$ \\
0,000
\end{tabular} & $\begin{array}{l}6,467 * * * * \\
0,001\end{array}$ & $\begin{array}{l}18,797^{\text {***** }} \\
0,000\end{array}$ & $\begin{array}{l}7,763^{\text {***** }} \\
0,000\end{array}$ & $\begin{array}{l}1,274 \\
0,279\end{array}$ & $\begin{array}{l}3,970^{* * * *} \\
0,010\end{array}$ & $\begin{array}{l}2,027^{*} \\
0,072\end{array}$ \\
\hline $\begin{array}{l}\text { Jumlah } \\
\text { Observasi }\end{array}$ & 79 & 73 & 42 & 42 & 85 & 80 & 85 & 80 \\
\hline Jumlah Bank & 13 & 13 & 10 & 10 & 13 & 13 & 13 & 13 \\
\hline
\end{tabular}

Data di atas merupakan hasil regresi dari estimasi persamaan (4). Kolom (1), (3), (5), dan (7) merupakan regresi interaksi pengaruh persentase komisaris independen dan kepemilikan asing terhadap risiko tanpa variabel kontrol. Kolom (2), (4), (6), dan (8) merupakan regresi interaksi pengaruh persentase komisaris independen dan kepemilikan asing terhadap risiko dengan variabel kontrol. FO merupakan proporsi kepemilikan asing sebagai ultimate shareholder di bank. Variabel dependen Z-score diperoleh dari penjumlahan ROA dan CAR dibagi deviasi standar ROA. Risiko sistematis dan risiko spesifik diperoleh dari regresi SIM, menggunakan return saham harian. VaR adalah Value at Risk yang dihitung dengan tingkat signifikansi $5 \%$, menggunakan metode historic or back simulation dari return saham harian. $*, * *, * * *$, berturut-turut signifikan pada $10 \%, 5 \%$, dan $1 \%$ 
Tabel 9. Regresi Interaksi Kualitas Manajemen Risiko dan Kepemilikan Asing terhadap Pengambilan Risiko

\begin{tabular}{|c|c|c|c|c|c|c|c|c|}
\hline \multirow{3}{*}{$\begin{array}{l}\text { V.Indepen- } \\
\text { den }\end{array}$} & \multicolumn{8}{|c|}{ Variabel Dependen } \\
\hline & \multicolumn{2}{|c|}{$\begin{array}{c}\text { Risiko Insolvency } \\
\text { (Z-score) }\end{array}$} & \multicolumn{2}{|c|}{$\begin{array}{c}\text { Risiko Sistematis } \\
\left(\beta^{2} \sigma_{\mathrm{m}}^{2}\right)\end{array}$} & \multicolumn{2}{|c|}{$\begin{array}{c}\text { Risiko Spesifik } \\
\left(\sigma^{2} \mathrm{e}_{\mathrm{it}}\right)\end{array}$} & \multicolumn{2}{|c|}{ VaR } \\
\hline & (1) & (2) & (3) & (4) & (5) & (6) & (7) & (8) \\
\hline $\begin{array}{l}\text { Kualitas } \\
\text { (t-stat) } \\
\text { (prob.) }\end{array}$ & $\begin{array}{l}-0,436 \\
(-1,244) \\
(0,219)\end{array}$ & $\begin{array}{l}0,129 \\
(0,291) \\
(0,772)\end{array}$ & $\begin{array}{l}-0,0005 \\
(-1,057) \\
(0,302)\end{array}$ & $\begin{array}{l}-0,00004 \\
(-0,061) \\
(0,951)\end{array}$ & $\begin{array}{l}-0,001^{\text {** }} \\
(-2,309) \\
(0,024)\end{array}$ & $\begin{array}{l}-0,001^{*} \\
(-1,849) \\
(0,070)\end{array}$ & $\begin{array}{l}-0,733 \\
(-0,980) \\
(0,332)\end{array}$ & $\begin{array}{l}-0,432 \\
(-0,557) \\
(0,579)\end{array}$ \\
\hline $\begin{array}{l}\text { FO } \\
\text { (t-stat) } \\
\text { (prob.) }\end{array}$ & $\begin{array}{l}-1,875^{*} \\
(-1,807) \\
(0,076)\end{array}$ & $\begin{array}{l}-0,392 \\
(-0,262) \\
(0,794)\end{array}$ & $\begin{array}{l}-0,001 \\
(-1,064) \\
(0,299)\end{array}$ & $\begin{array}{l}0,00006 \\
(0,021) \\
(0,983)\end{array}$ & $\begin{array}{l}-0,004^{* *} \\
(-2,223) \\
(0,030)\end{array}$ & $\begin{array}{l}-0,004^{*} \\
(-1,965) \\
(0,055)\end{array}$ & $\begin{array}{l}-1,518^{*} \\
(-0,537) \\
(0,059)\end{array}$ & $\begin{array}{l}-0,312 \\
(-0,122) \\
(0,903)\end{array}$ \\
\hline $\begin{array}{l}\text { Kualitas*FO } \\
\text { (t-stat) } \\
\text { (prob.) }\end{array}$ & $\begin{array}{l}1,024^{* * *} \\
(1,995) \\
(0,051)\end{array}$ & $\begin{array}{l}0,270 \\
(0,448) \\
(0,655)\end{array}$ & $\begin{array}{l}0,0003 \\
(0,522) \\
(0,607)\end{array}$ & $\begin{array}{l}-0,0001 \\
(-0,126) \\
(0,901)\end{array}$ & $\begin{array}{l}0,0015^{*} \\
(1,842) \\
(0,070)\end{array}$ & $\begin{array}{l}0,001 \\
(1,601) \\
(0,115)\end{array}$ & $\begin{array}{l}0,552 \\
(0,540) \\
(0,591)\end{array}$ & $\begin{array}{l}0,175 \\
(0,170) \\
(0,865)\end{array}$ \\
\hline $\begin{array}{l}N P L \\
\text { (t-stat) } \\
\text { (prob.) }\end{array}$ & & $\begin{array}{l}-11,080^{*} \\
(-1,743) \\
(0,088)\end{array}$ & & $\begin{array}{l}0,037 \text { *** } \\
(2,245) \\
(0,038)\end{array}$ & & $\begin{array}{l}0,005 \\
(0,649) \\
(0,519)\end{array}$ & & $\begin{array}{l}7,730 \\
(1,012) \\
(0,316)\end{array}$ \\
\hline $\begin{array}{l}L D R \\
\text { (t-stat) } \\
\text { (prob.) }\end{array}$ & & $\begin{array}{l}-1,562 * * \\
(-2,042) \\
(0,047)\end{array}$ & & $\begin{array}{l}-0,0008 \\
(-4,811) \\
(0,636)\end{array}$ & & $\begin{array}{l}-0,002 \\
(-0,875) \\
(0,385)\end{array}$ & & $\begin{array}{l}0,207 \\
(0,125) \\
(0,901)\end{array}$ \\
\hline $\begin{array}{l}C I \\
\text { (t-stat) } \\
\text { (prob.) }\end{array}$ & & $\begin{array}{l}-4,571 * * * \\
(-3,864) \\
0,000\end{array}$ & & $\begin{array}{l}0,0007 \\
(0,381) \\
(0,707)\end{array}$ & & $\begin{array}{l}0,002 \\
(1,185) \\
(0,241)\end{array}$ & & $\begin{array}{l}-1,207 \\
(-0,644) \\
(0,522)\end{array}$ \\
\hline $\begin{array}{l}\text { Konstanta } \\
\text { (t-stat.) } \\
\text { (prob.) }\end{array}$ & $\begin{array}{l}5,813 \text { *** } \\
(9,332) \\
(0,000) \\
\end{array}$ & $\begin{array}{l}10,100^{\text {**** }} \\
(8,132) \\
(0,000)\end{array}$ & $\begin{array}{l}0,002 * * \\
(2,065) \\
(0,052) \\
\end{array}$ & $\begin{array}{l}0,00001 \\
(0,008) \\
(0,993)\end{array}$ & $\begin{array}{l}0,004 \text { *** } \\
(3,224) \\
(0,002) \\
\end{array}$ & $\begin{array}{l}0,004 \\
(1,603) \\
(0,115)\end{array}$ & $\begin{array}{l}2,475 \\
(1,229) \\
(0,225) \\
\end{array}$ & $\begin{array}{l}2,066 \\
(0,839) \\
(0,405)\end{array}$ \\
\hline $\mathrm{R}^{2}$ & 0,149 & 0,402 & 0,411 & $(0,377)$ & 0,131 & 0,151 & 0,585 & 0,008 \\
\hline $\begin{array}{l}\text { F-statistik } \\
\text { Prob.F-statistik }\end{array}$ & $\begin{array}{l}4,050^{* * * *} \\
0,011\end{array}$ & $\begin{array}{l}6,281^{* * * *} \\
0,000\end{array}$ & $\begin{array}{l}6,362^{\text {**** }} \\
0,003\end{array}$ & $\begin{array}{l}3,321^{\text {*** }} \\
0,023\end{array}$ & $\begin{array}{l}3,913 \text { *** } \\
0,013\end{array}$ & $\begin{array}{l}2,571^{\text {** }} \\
0,031\end{array}$ & $\begin{array}{l}6,844^{\text {**** }} \\
0,000\end{array}$ & $\begin{array}{l}1,077 \\
0,389 \\
\end{array}$ \\
\hline $\begin{array}{l}\text { Jumlah } \\
\text { Observasi }\end{array}$ & 53 & 48 & 24 & 24 & 59 & 54 & 59 & 54 \\
\hline Jumlah Bank & 12 & 12 & 8 & 7 & 12 & 12 & 12 & 12 \\
\hline
\end{tabular}

Kom $(1),(3),(5)$, dan (7) merupakan regresi interaksi pengaruh kualitas manajemen risiko dan kepemilikan asing terhadap risiko tanpa variabel kontrol. Kolom (2), (4), (6), dan (8) merupakan regresi interaks pengaruh kualitas manajemeen risiko dan kepemilikan asing terhadap risiko dengan variabel kontrol. FO merupakan proporsi kepemilikan asing proporsi kepemilikan asing sebagai ultimate shareholder di bank. Variabel dependen Z-score diperoleh dari penjumlahan ROA dan CAR dibagi deviasi standar ROA. Risiko sistematis dan risiko spesifik diperoleh dari regresi SIM, menggunakan return saham harian. VaR adalah Value at Risk yang dihitung dengan tingkat signifikansi 5\%, menggunakan metode historic or back simulation dari return saham harian.

$*, * *, * *$, berturut-turut signifikan pada $10 \%, 5 \%$, dan $1 \%$.

Tabel 10. Regresi Interaksi Jumlah Rapat Komisaris dan Direksi dan Kepemilikan Asing terhadap Pengambilan Risiko

\begin{tabular}{|c|c|c|c|c|c|c|c|c|}
\hline \multirow{3}{*}{$\begin{array}{l}\text { V.Indepen- } \\
\text { den }\end{array}$} & \multicolumn{8}{|c|}{ Variabel Dependen } \\
\hline & \multicolumn{2}{|c|}{$\begin{array}{c}\text { Risiko Insolvency } \\
\text { (Z-score })\end{array}$} & \multicolumn{2}{|c|}{$\begin{array}{c}\text { Risiko Sistematis } \\
\left(\beta^{2} \sigma_{\mathrm{m}}^{2}\right)\end{array}$} & \multicolumn{2}{|c|}{$\begin{array}{c}\text { Risiko Spesifik } \\
\left(\sigma^{2} \mathrm{e}_{i t}\right)\end{array}$} & \multicolumn{2}{|c|}{ VaR } \\
\hline & (1) & (2) & (3) & (4) & (5) & (6) & (7) & (8) \\
\hline $\begin{array}{l}\text { Rapat } \\
\text { (t-stat) } \\
\text { (prob.) }\end{array}$ & \begin{tabular}{|l}
$-0,637^{*}$ \\
$(-1,720)$ \\
$(0,096)$
\end{tabular} & $\begin{array}{l}1,581 \\
(1,293) \\
(0,209)\end{array}$ & $\begin{array}{l}0,0008 \\
(0,064) \\
(0,950)\end{array}$ & $\begin{array}{l}-0,002 \\
(1,144) \\
(0,289)\end{array}$ & $\begin{array}{l}-0,052^{\text {**** }} \\
(-4,001) \\
(0,000)\end{array}$ & $\begin{array}{l}-0,046^{* * * *} \\
(-3029) \\
(0,009)\end{array}$ & $\begin{array}{l}0,191 \\
(0,693) \\
(0,493)\end{array}$ & $\begin{array}{l}-0,802 \\
(-0,877) \\
(0,389)\end{array}$ \\
\hline $\begin{array}{l}\text { FO } \\
\text { (t-stat) } \\
\text { (prob.) }\end{array}$ & \begin{tabular}{|l|}
$-1,034$ \\
$(-1,720)$ \\
$(0,484)$
\end{tabular} & $\begin{array}{l}1,264 \\
(0,273) \\
(0,787)\end{array}$ & $\begin{array}{l}-0,0005 \\
(-0,064) \\
(0,949)\end{array}$ & $\begin{array}{l}-0,011 \\
(-1,401) \\
(0,203)\end{array}$ & $\begin{array}{l}-0,194 \text { **** } \\
(-4,071) \\
(0,000)\end{array}$ & $\begin{array}{l}-0,202^{* * * *} \\
(-3,689) \\
(0,002)\end{array}$ & $\begin{array}{l}1,293 \\
(1,076) \\
(0,290)\end{array}$ & $\begin{array}{l}-0,847 \\
(-0,272) \\
(0,787)\end{array}$ \\
\hline $\begin{array}{l}\text { Rapat*FO } \\
\text { (t-stat) } \\
\text { (prob.) }\end{array}$ & \begin{tabular}{|l|}
1,035 \\
$(1,390)$ \\
$(0,175)$ \\
\end{tabular} & $\begin{array}{l}-0,746 \\
(-0,371) \\
(0,714) \\
\end{array}$ & $\begin{array}{l}-0,0002 \\
(-0,052) \\
(0,958) \\
\end{array}$ & $\begin{array}{l}0,004 \\
(1,283) \\
(0,240)\end{array}$ & $\begin{array}{l}0,083^{* * * *} \\
(3,943) \\
(0,000)\end{array}$ & $\begin{array}{l}0,085^{* * * *} \\
(3,462) \\
(0,003\end{array}$ & $\begin{array}{l}-0,452 \\
(-0,890) \\
(0,380)\end{array}$ & $\begin{array}{l}0,655 \\
(0,478) \\
(0,637)\end{array}$ \\
\hline $\begin{array}{l}N P L \\
\text { (t-stat) } \\
\text { (prob.) }\end{array}$ & & $\begin{array}{l}-65,031^{\text {***** }} \\
(-6,872) \\
(0,000)\end{array}$ & & $\begin{array}{l}0,041^{\text {**** }} \\
(3,744) \\
(0,007)\end{array}$ & & $\begin{array}{l}-0,016 \\
(-0,161) \\
(0,874)\end{array}$ & & $\begin{array}{l}31,407 \text { *** } \\
(4,510) \\
(0,000)\end{array}$ \\
\hline $\begin{array}{l}L D R \\
\text { (t-stat) } \\
\text { (prob.) }\end{array}$ & & $\begin{array}{l}-0,736^{*} \\
(-1,626) \\
(0,118)\end{array}$ & & $\begin{array}{l}-0,001^{* *} \\
(-2,893) \\
(0,023)\end{array}$ & & $\begin{array}{l}-0,030^{*} \\
(-1,724) \\
(0,1067)\end{array}$ & & $\begin{array}{l}-2,231^{\text {***** }} \\
(-6,899) \\
(0,000)\end{array}$ \\
\hline $\begin{array}{l}C I \\
\text { (t-stat) } \\
\text { (prob.) }\end{array}$ & & $\begin{array}{l}-3,474 * * * * \\
(-3,566) \\
(0,001)\end{array}$ & & $\begin{array}{l}0,001 \\
(0,811) \\
(0,443)\end{array}$ & & $\begin{array}{l}0,018 \\
(1,630) \\
(0,125)\end{array}$ & & $\begin{array}{l}-1,377 * * \\
(-2,633) \\
(0,015)\end{array}$ \\
\hline $\begin{array}{l}\text { Konstanta } \\
\text { (t-stat.) } \\
\text { (prob.) }\end{array}$ & $\begin{array}{l}5,725^{\text {**** }} \\
(13,190) \\
(0,000)\end{array}$ & $\begin{array}{l}6,888^{* * * * *} \\
(2,213) \\
(0,004)\end{array}$ & $\begin{array}{l}0,0008 \\
(0,135) \\
(0,894)\end{array}$ & $\begin{array}{l}0,007 \\
(1,371) \\
(0,212)\end{array}$ & $\begin{array}{l}0,125 * * * \\
(4,182) \\
(0,000)\end{array}$ & $\begin{array}{l}0,130 * * * \\
(3,879) \\
(0,001)\end{array}$ & $\begin{array}{l}-0,216 \\
(-0,341) \\
(0,735)\end{array}$ & $\begin{array}{l}4,129 * \\
(1,909) \\
(0,068)\end{array}$ \\
\hline $\mathrm{R}^{2}$ & 0,008 & 0,900 & $-0,094$ & 0,749 & 0,327 & 0,597 & $-0,047$ & 0,933 \\
\hline $\begin{array}{l}\text { F-statistik } \\
\text { Prob.F- } \\
\text { statistik }\end{array}$ & $\begin{array}{l}, 087 \\
0,370\end{array}$ & $\begin{array}{l}43,052^{\text {**** }} \\
0,000\end{array}$ & $\begin{array}{l}0,625 \\
0,614\end{array}$ & $\begin{array}{l}7,496^{* * * *} \\
0,008\end{array}$ & $\begin{array}{l}2,197 * \\
0,057\end{array}$ & $\begin{array}{l}3,866^{* * * *} \\
0,007\end{array}$ & $\begin{array}{l}0,520 \\
0,671\end{array}$ & $\begin{array}{l}68,643 \text { **** } \\
0,000\end{array}$ \\
\hline $\begin{array}{l}\text { Jumlah } \\
\text { Observasi }\end{array}$ & 32 & 29 & 14 & 14 & 33 & 30 & 33 & 30 \\
\hline Jumlah Bank & 11 & 10 & 4 & 6 & 11 & 10 & 11 & 10 \\
\hline
\end{tabular}

Data di atas merupakan hasil regresi dari estimasi persamaan (4). Kolom (1), (3), (5), dan (7) merupakan regresi interaksi pengaruh rapat komisaris dan direksi dan kepemilikan asing terhadap risiko tanpa variabel kontrol. Kolom (2), (4), (6), dan (8) merupakan regresi interaksi pengaruh rapat komisaris dan direksi dan kepemilikan asing terhadap risiko dengan variabel kontrol. FO merupakan proporsi kepemilikan asing di bank. Variabel dependen Z-score diperoleh dari penjumlahan ROA dan CAR dibagi deviasi standar ROA. Risiko sistematis dan risiko spesifik diperoleh dari regresi SIM, menggunakan return saham harian. VaR adalah Value at Risk yang dihitung dengan tingkat signifikansi $5 \%$, menggunakan metode historic or back simulation dari return saham harian.

$*, * *, * * *$, berturut-turut signifikan pada $10 \%, 5 \%$, dan $1 \%$. 
Tabel 11. Regresi Interaksi Jumlah Komisaris dan Kepemilikan Domestik terhadap Pengambilan Risiko

\begin{tabular}{|c|c|c|c|c|c|c|c|c|}
\hline \multirow{3}{*}{$\begin{array}{l}\text { V.Indepen- } \\
\text { den }\end{array}$} & \multicolumn{8}{|c|}{ Variabel Dependen } \\
\hline & \multicolumn{2}{|c|}{$\begin{array}{c}\text { Risiko Insolvency } \\
\text { (Z-score })\end{array}$} & \multicolumn{2}{|c|}{$\begin{array}{l}\text { Risiko Sistematis } \\
\left(\beta^{2} \sigma_{\mathrm{m}}^{2}\right)\end{array}$} & \multicolumn{2}{|c|}{$\begin{array}{l}\text { Risiko Spesifik } \\
\left(\sigma^{2} \mathrm{e}_{\mathrm{it}}\right)\end{array}$} & \multicolumn{2}{|c|}{ VaR } \\
\hline & (1) & (2) & (3) & (4) & (5) & (6) & (7) & (8) \\
\hline $\begin{array}{l}\text { Komisaris } \\
\text { (t-stat) } \\
\text { (prob.) }\end{array}$ & $\begin{array}{l}0,218^{*} \\
(1,704) \\
(0,089)\end{array}$ & $\begin{array}{l}0,106 \\
(1,073) \\
(0,284)\end{array}$ & $\begin{array}{l}-0,001 \\
(-1,516) \\
(0,132)\end{array}$ & $\begin{array}{l}-0,0009 \\
(-0,881) \\
(0,380)\end{array}$ & $\begin{array}{l}-0,002^{* * * *} \\
(-3,684) \\
(0,000)\end{array}$ & $\begin{array}{l}-0,003 * * * \\
(-4,352) \\
(0,000)\end{array}$ & $\begin{array}{l}0,107 \\
(1,542) \\
(0,124)\end{array}$ & $\begin{array}{l}-0,493^{*} \\
(-1,676) \\
(0,095)\end{array}$ \\
\hline $\begin{array}{l}\text { DO } \\
\text { (t-stat) } \\
\text { (prob.) } \\
\end{array}$ & $\begin{array}{l}1,035 \\
(1,328) \\
(0,185) \\
\end{array}$ & $\begin{array}{l}0,649 \\
(0,790) \\
(0,284) \\
\end{array}$ & $\begin{array}{l}0,003 \\
(-1,342) \\
(0,182) \\
\end{array}$ & $\begin{array}{l}0,0005 \\
(0,270) \\
(0,787) \\
\end{array}$ & $\begin{array}{l}-0,001 \\
(-1,287) \\
(0,206) \\
\end{array}$ & $\begin{array}{l}-0,0019^{*} \\
(-1,643) \\
(0,102) \\
\end{array}$ & $\begin{array}{l}-0,429 \\
(-0,892) \\
(0,373) \\
\end{array}$ & $\begin{array}{l}-2,054^{\text {**** }}(-3,525) \\
(0,000) \\
\end{array}$ \\
\hline $\begin{array}{l}\text { Kom*DO } \\
\text { (t-stat) } \\
\text { (prob.) }\end{array}$ & $\begin{array}{l}-0,933 \\
(-1,315) \\
(0,189) \\
\end{array}$ & $\begin{array}{l}-0,135 \\
(-0,213) \\
(0,831)\end{array}$ & $\begin{array}{l}0,002 \\
(1,464) \\
(0,146)\end{array}$ & $\begin{array}{l}-0,0003 \\
(-0,202) \\
(0,840) \\
\end{array}$ & $\begin{array}{l}0,001 \\
(1,268) \\
(0,206) \\
\end{array}$ & $\begin{array}{l}0,0017^{*} \\
(1,622) \\
(0,106) \\
\end{array}$ & $\begin{array}{l}0,388 \\
(0,887) \\
(0,376) \\
\end{array}$ & $\begin{array}{l}1,868 \text { **** } \\
(3,521) \\
(0,000) \\
\end{array}$ \\
\hline $\begin{array}{l}N P L \\
\text { (t-stat) } \\
\text { (prob.) } \\
\end{array}$ & & $\begin{array}{l}-3,967 * * * \\
(-3,043) \\
(0,002)\end{array}$ & & $\begin{array}{l}0,013^{\text {*** }} \\
(2,962) \\
(0,003)\end{array}$ & & $\begin{array}{l}0,0017 \\
(0,677) \\
(0,498) \\
\end{array}$ & & $\begin{array}{l}-1,238^{* *} \\
(-2,072) \\
(0,039) \\
\end{array}$ \\
\hline $\begin{array}{l}L D R \\
\text { (t-stat) } \\
\text { (prob.) }\end{array}$ & & $\begin{array}{l}-0,872 \text { *** } \\
(-2,753) \\
(0,006)\end{array}$ & & $\begin{array}{l}0,0007 * \\
(1,782) \\
(0,077)\end{array}$ & & $\begin{array}{l}0,0016^{\text {**** }} \\
(2,486) \\
(0,014)\end{array}$ & & $\begin{array}{l}-0,949 \text { *** } \\
(-3,328) \\
(0,001)\end{array}$ \\
\hline $\begin{array}{l}C I \\
\text { (t-stat) } \\
\text { (prob.) } \\
\end{array}$ & & $\begin{array}{l}-0,098 \\
(-0,389) \\
(0,697) \\
\end{array}$ & & $\begin{array}{l}-0,0006 \text { **** } \\
(-3,253) \\
(0,001)\end{array}$ & & $\begin{array}{l}-0,0002 \\
(-0,741) \\
(0,459) \\
\end{array}$ & & $\begin{array}{l}0,150 \text { **** } \\
(2,999) \\
(0,003) \\
\end{array}$ \\
\hline $\begin{array}{l}\text { Konstanta } \\
\text { (t-stat.) } \\
\text { (prob.) }\end{array}$ & $\begin{array}{l}4,016 \text { *** } \\
(8,429) \\
(0,000)\end{array}$ & $\begin{array}{l}4,959 * * * \\
(8,524) \\
(0,000)\end{array}$ & $\begin{array}{l}0,003^{*} \\
(1,927) \\
(0,056)\end{array}$ & $\begin{array}{l}0,001 \\
(1,176) \\
(0,242)\end{array}$ & $\begin{array}{l}0,004 * * * \\
(5,545) \\
(0,000)\end{array}$ & $\begin{array}{l}0,004 * * * \\
(4,946) \\
(0,000)\end{array}$ & $\begin{array}{l}-0,038 \\
(-0,175) \\
(0,861) \\
\end{array}$ & $\begin{array}{l}1,500^{* * * *} \\
(3,581) \\
(0,000)\end{array}$ \\
\hline $\mathrm{R}^{2}$ & 0,002 & 0,398 & $-0,004$ & 0,241 & 0,185 & 0,217 & 0,121 & 0,156 \\
\hline $\begin{array}{l}\text { F-statistik } \\
\text { Prob.F- } \\
\text { statistik }\end{array}$ & $\begin{array}{l}1,064 \\
0,304\end{array}$ & $\begin{array}{l}27,785^{* * *} \\
0,000\end{array}$ & $\begin{array}{l}0,823 \\
0,483\end{array}$ & $\begin{array}{l}6,693^{* * * *} \\
0,000\end{array}$ & $\begin{array}{l}14,039^{\text {***** }} \\
0,000\end{array}$ & $\begin{array}{l}8,552^{\text {**** }} \\
0,000\end{array}$ & $\begin{array}{l}9,120^{\text {***** }} \\
0,000\end{array}$ & $\begin{array}{l}6,173^{* * * *} \\
0,000\end{array}$ \\
\hline $\begin{array}{l}\text { Jumlah } \\
\text { Observasi }\end{array}$ & 255 & 244 & 113 & 108 & 173 & 164 & 177 & 168 \\
\hline $\begin{array}{l}\text { Jumlah } \\
\text { Bank }\end{array}$ & 34 & 34 & 32 & 32 & 32 & 32 & 32 & 32 \\
\hline
\end{tabular}

Data di atas merupakan hasil regresi dari estimasi persamaan (5). Kolom (1), (3), (5), dan (7) merupakan pengaruh interaksi jumlah komisaris dan kepemilikan domestik terhadap risiko tanpa variabel kontrol. Kolom (2), (4), (6), dan (8) merupakan re gresi interaksi pengaruh jumlah komisaris dan kepemilikan domestik terhadap risiko dengan variabel kontrol. FD merupakan proporsi kepemilikan domestik proporsi kepemilikan asing sebagai ultimate shareholder di bank. Variabel dependen Z-score diperoleh dari penjumlahan ROA dan CAR dibagi deviasi standar ROA. Risiko sistematis dan risiko spesifik diperoleh dari regresi SIM, menggunakan return saham harian. VaR adalah Value at Risk yang dihitung dengan tingkat signifikansi 5\%, menggunakan metode historic or back simulation dari return saham harian. $*, * *, * * *$, berturut-turut signifikan pada $10 \%, 5 \%$, dan $1 \%$.

Tabel 12. Regresi Interaksi Persentase Komisaris Independen dan Kepemilikan Domestik terhadap Pengambilan Risiko

\begin{tabular}{|c|c|c|c|c|c|c|c|c|}
\hline \multirow{3}{*}{ V.Independen } & \multicolumn{8}{|c|}{ Variabel Dependen } \\
\hline & \multicolumn{2}{|c|}{$\begin{array}{c}\text { Risiko Insolvency } \\
\text { (Z-score })\end{array}$} & \multicolumn{2}{|c|}{$\begin{array}{c}\text { Risiko Sistematis } \\
\left(\beta^{2} \sigma_{\mathrm{m}}^{2}\right)\end{array}$} & \multicolumn{2}{|c|}{$\begin{array}{c}\text { Risiko Spesifik } \\
\left(\sigma^{2} \mathrm{e}_{\mathrm{it}}\right)\end{array}$} & \multicolumn{2}{|c|}{ VaR } \\
\hline & (1) & (2) & (3) & (4) & (5) & (6) & (7) & (8) \\
\hline $\begin{array}{l}\text { Kom_Indp } \\
\text { (t-stat) } \\
\text { (prob.) }\end{array}$ & $\begin{array}{l}2,346^{* * * *} \\
(4,099) \\
(0,000)\end{array}$ & $\begin{array}{l}2,173^{* * * *} \\
(3,678) \\
(0,000)\end{array}$ & $\begin{array}{l}-0,025 * * * * \\
(-11,464) \\
(0,000)\end{array}$ & $\begin{array}{l}-0,021^{* * * *} \\
(-8,253) \\
(0,000)\end{array}$ & $\begin{array}{l}-0,006^{* * * * *} \\
(-4,562) \\
(0,000)\end{array}$ & $\begin{array}{l}-0,007^{* * * *} \\
(-4,467) \\
(0,000)\end{array}$ & $\begin{array}{l}0,891^{*} \\
(1,748) \\
(0,082)\end{array}$ & $\begin{array}{l}2,275^{* * * *} \\
(4,048) \\
(0,000)\end{array}$ \\
\hline $\begin{array}{l}\text { DO } \\
\text { (t-stat) } \\
\text { (prob.) }\end{array}$ & $\begin{array}{l}1,105^{* * * *} \\
(3,396) \\
(0,001)\end{array}$ & $\begin{array}{l}1,208^{* * * *} \\
(3,562) \\
(0,000)\end{array}$ & $\begin{array}{l}-0,015 \text { *** } \\
(-6,726) \\
(0,000)\end{array}$ & $\begin{array}{l}-0,014 * * * \\
(-5,322) \\
(0,000)\end{array}$ & $\begin{array}{l}-0,005^{* * * *} \\
(-3,212) \\
(0,002)\end{array}$ & $\begin{array}{l}-0,005^{* *} \\
(-2,448) \\
(0,015)\end{array}$ & $\begin{array}{l}0,812 \\
(1,415) \\
(0,158)\end{array}$ & $\begin{array}{l}2,288^{* * * *} \\
(3,523) \\
(0,001)\end{array}$ \\
\hline $\begin{array}{l}\text { Kom_Indp*DO } \\
\text { (t-stat) } \\
\text { (prob.) }\end{array}$ & $\begin{array}{l}-3,718^{* * * *} \\
(-4,641) \\
(0,000)\end{array}$ & $\begin{array}{l}-3,297 \text { **** } \\
(-3,850) \\
(0,000)\end{array}$ & $\begin{array}{l}0,029 * * * \\
(6,690) \\
(0,000)\end{array}$ & $\begin{array}{l}0,025^{\text {**** }} \\
(4,887) \\
(0,000) \\
\end{array}$ & $\begin{array}{l}0,008^{\text {***** }} \\
(3,206) \\
(0,002)\end{array}$ & $\begin{array}{l}0,007 * * \\
(2,444) \\
(0,016)\end{array}$ & $\begin{array}{l}-1,227 \\
(-1,424) \\
(0,156)\end{array}$ & $\begin{array}{l}-3,441 * * * \\
(-3,533) \\
(0,001)\end{array}$ \\
\hline $\begin{array}{l}N P L \\
\text { (t-stat) } \\
\text { (prob.) }\end{array}$ & & $\begin{array}{l}-2,637^{* * *} \\
(-2,127) \\
0,034\end{array}$ & & $\begin{array}{l}0,010^{* * * *} \\
(2,599) \\
(0,011)\end{array}$ & & $\begin{array}{l}0,002 \\
(0,657) \\
(0,512)\end{array}$ & & $\begin{array}{l}-2,893 \\
(-4,387) \\
(0,000)\end{array}$ \\
\hline $\begin{array}{l}L D R \\
\text { (t-stat) } \\
\text { (prob.) } \\
\end{array}$ & & $\begin{array}{l}-0,812^{* * * * *} \\
(-2,706) \\
(0,007) \\
\end{array}$ & & $\begin{array}{l}0,002 * * * \\
(4,887) \\
(0,000) \\
\end{array}$ & & $\begin{array}{l}0,001 * * \\
(2,015) \\
(0,045)\end{array}$ & & $\begin{array}{l}-1,928 \\
(-6,979) \\
(0,000) \\
\end{array}$ \\
\hline $\begin{array}{l}C I \\
\text { (t-stat) } \\
\text { (prob.) }\end{array}$ & & $\begin{array}{l}-0,363 \\
(-1,001) \\
(0,318)\end{array}$ & & $\begin{array}{l}-0,0002 \\
(-1,119) \\
(0,265)\end{array}$ & & $\begin{array}{l}0,00003 \\
(0,108) \\
(0,914)\end{array}$ & & $\begin{array}{l}-0,026 \\
(-0,528) \\
(0,597)\end{array}$ \\
\hline $\begin{array}{l}\text { Konstanta } \\
\text { (t-stat.) } \\
\text { (prob.) }\end{array}$ & $\begin{array}{l}4,098^{* * * *} \\
(16,463) \\
(0,000)\end{array}$ & $\begin{array}{l}4,979 * * * \\
(10,437) \\
(0,000)\end{array}$ & $\begin{array}{l}0,014 * * * \\
(12,588) \\
(0,000)\end{array}$ & $\begin{array}{l}0,011 \text { **** } \\
(8,427) \\
(0,000) \\
\end{array}$ & $\begin{array}{l}0,005^{* * * *} \\
(5,693) \\
(0,000)\end{array}$ & $\begin{array}{l}0,004^{* * * *} \\
(4,214) \\
(0,000) \\
\end{array}$ & $\begin{array}{l}-0,051 \\
(-0,158) \\
(0,874)\end{array}$ & $\begin{array}{l}0,818^{* *} \\
(2,085) \\
(0,038)\end{array}$ \\
\hline $\mathrm{R}^{2}$ & 0,068 & 0,093 & 0,657 & 0,621 & 0,113 & 0,137 & 0,002 & 0,359 \\
\hline $\begin{array}{l}\text { F-statistik } \\
\text { Prob.F-statistik }\end{array}$ & $\begin{array}{l}7,466 * * * * \\
0,000\end{array}$ & $\begin{array}{l}5,163^{* * * * *} \\
0,000\end{array}$ & $\begin{array}{l}72,683^{\text {****** }} \\
0,000\end{array}$ & $\begin{array}{l}30,262^{* * * * *} \\
0,000\end{array}$ & $\begin{array}{l}8,329 \text { **** } \\
0,000\end{array}$ & $\begin{array}{l}5,334 * * * * \\
0,000\end{array}$ & $\begin{array}{l}1,153 \\
0,329 \\
\end{array}$ & $\begin{array}{l}16,596^{* * * * *} \\
0,000\end{array}$ \\
\hline $\begin{array}{l}\text { Jumlah } \\
\text { Observasi }\end{array}$ & 266 & 244 & 113 & 108 & 173 & 164 & 177 & 168 \\
\hline Jumlah Bank & 34 & 34 & 28 & 27 & 32 & 32 & 32 & 32 \\
\hline
\end{tabular}

Data di atas merupakan hasil regresi dari estimasi persamaan (5). Kolom (1), (3), (5), dan (7) merupakan pengaruh interaksi komisaris independen dan kepemilikan domestik terhadap risiko tanpa variabel kontrol. Kolom (2), (4), (6), dan (8) merupakan regresi interaksi pengaruh komisaris independen dan kepemilikan domestik terhadap risiko dengan variabel kontrol. FD merupakan proporsi kepemilikan domestik di bank. Variabel dependen Z-score diperoleh dari penjumlahan ROA dan CAR dibagi deviasi standar ROA. Risiko sistematis dan risiko spesifik diperoleh dari regresi SIM, menggunakan return saham harian. VaR adalah Value at Risk yang dihitung dengan tingkat signifikansi 5\%, menggunakan metode historic or back simulation dari return saham harian.

$*, * *, * * *$, berturut-turut signifikan pada $10 \%, 5 \%$, dan $1 \%$. 
Tabel 13. Regresi Interaksi Kualitas Manajemen Risiko dan Kepemilikan Domestik terhadap Pengambilan Risiko

\begin{tabular}{|c|c|c|c|c|c|c|c|c|}
\hline \multirow{3}{*}{$\begin{array}{l}\text { V.Indepen- } \\
\text { den }\end{array}$} & \multicolumn{8}{|c|}{ Variabel Dependen } \\
\hline & \multicolumn{2}{|c|}{$\begin{array}{c}\text { Risisko Insolvency } \\
\text { (Z-score) }\end{array}$} & \multicolumn{2}{|c|}{$\begin{array}{c}\text { Risiko Sistematis } \\
\left(\beta^{2} \sigma_{\mathrm{m}}^{2}\right)\end{array}$} & \multicolumn{2}{|c|}{$\begin{array}{c}\text { Risiko Spesifik } \\
\left(\sigma^{2} \mathrm{e}_{i t}\right)\end{array}$} & \multicolumn{2}{|c|}{ VaR } \\
\hline & (1) & (2) & (3) & (4) & (5) & (6) & (7) & (8) \\
\hline $\begin{array}{l}\text { Kualitas } \\
\text { (t-stat) } \\
\text { (prob.) }\end{array}$ & $\begin{array}{l}0,332 \\
(1,333) \\
(0,185)\end{array}$ & $\begin{array}{l}0,280 \\
(1,066) \\
(0,288)\end{array}$ & $\begin{array}{l}-0,001^{\text {**** }} \\
(-2,880) \\
(0,005)\end{array}$ & $\begin{array}{l}-0,001 \text { *** } \\
(-2,770) \\
(0,007)\end{array}$ & $\begin{array}{l}-0,001 \text { *** } \\
(-4,773) \\
(0,000)\end{array}$ & $\begin{array}{l}-0,001^{* * *} \\
(-4,962) \\
(0,000)\end{array}$ & $\begin{array}{l}0,175 \\
(0,916) \\
(0,361)\end{array}$ & $\begin{array}{l}0,245 \\
(1,256) \\
(0,211)\end{array}$ \\
\hline $\begin{array}{l}\text { DO } \\
\text { (t-stat) } \\
\text { (prob.) }\end{array}$ & $\begin{array}{l}-0,233 \\
(-0,375) \\
(0,708)\end{array}$ & $\begin{array}{l}0,033 \\
(0,049) \\
(0,960)\end{array}$ & $\begin{array}{l}-0,001 \\
(-1,234) \\
(0,220)\end{array}$ & $\begin{array}{l}-0,001 \\
(-0,849) \\
(0,398)\end{array}$ & $\begin{array}{l}-0,002 * * * \\
(-3,758) \\
(0,000)\end{array}$ & $\begin{array}{l}-0,003 * * * \\
(-3,920) \\
(0,000)\end{array}$ & $\begin{array}{l}0,228 \\
(0,311) \\
(0,756)\end{array}$ & $\begin{array}{l}0,552 \\
(0,696) \\
(0,487)\end{array}$ \\
\hline $\begin{array}{l}\text { Kualitas*DO } \\
\text { (t-stat) } \\
\text { (prob.) }\end{array}$ & $\begin{array}{l}-0,483 \\
(-1,239) \\
(0,217)\end{array}$ & $\begin{array}{l}-0,543 \\
(-1,355) \\
(0,178)\end{array}$ & $\begin{array}{l}0,001^{\text {** }} \\
(1,970) \\
(0,052)\end{array}$ & $\begin{array}{l}0,001 * \\
(1,904) \\
(0,061)\end{array}$ & $\begin{array}{l}0,001^{* * * *} \\
(3,747) \\
(0,000)\end{array}$ & $\begin{array}{l}0,001^{\text {**** }} \\
(3,912) \\
(0,000)\end{array}$ & $\begin{array}{l}-0,094 \\
(-0,319) \\
(0,750)\end{array}$ & $\begin{array}{l}-0,224 \\
(-0,704) \\
(0,487)\end{array}$ \\
\hline $\begin{array}{l}N P L \\
\text { (t-stat) } \\
\text { (prob.) }\end{array}$ & & $\begin{array}{l}-2,320 \\
(-1,178) \\
(0,241)\end{array}$ & & $\begin{array}{l}0,006^{*} \\
(1,825) \\
(0,072)\end{array}$ & & $\begin{array}{l}-0,002^{* *} \\
(-1,999) \\
(0,048)\end{array}$ & & $\begin{array}{l}-0,224 \\
(-0,704) \\
(0,483)\end{array}$ \\
\hline $\begin{array}{l}L D R \\
\text { (t-stat) } \\
\text { (prob.) }\end{array}$ & & $\begin{array}{l}0,054 \\
(0,113) \\
(0,909)\end{array}$ & & $\begin{array}{l}-0,001 \text { ** } \\
(-2,376) \\
(0,020)\end{array}$ & & $\begin{array}{l}0,0002 \\
(0,330) \\
(0,714)\end{array}$ & & $\begin{array}{l}-2,493 \text { *** } \\
(-5,642) \\
(0,000)\end{array}$ \\
\hline $\begin{array}{l}C I \\
\text { (t-stat) } \\
\text { (prob.) }\end{array}$ & & $\begin{array}{l}-0,789 \\
(-1,134) \\
(0,259)\end{array}$ & & $\begin{array}{l}-0,0003 \text { *** } \\
(-2,826) \\
(0,006)\end{array}$ & & $\begin{array}{l}\text { 0,00006* } \\
(1,698) \\
(0,092)\end{array}$ & & $\begin{array}{l}0,036 \\
(0,658) \\
(0,511)\end{array}$ \\
\hline $\begin{array}{l}\text { Konstanta } \\
\text { (t-stat.) } \\
\text { (prob.) }\end{array}$ & $\begin{array}{l}4,937 \text { *** } \\
(11,296) \\
(0,000)\end{array}$ & $\begin{array}{l}5,578^{\text {**** }} \\
(7,384) \\
(0,000)\end{array}$ & $\begin{array}{l}0,002 * * * \\
(3,310) \\
(0,001)\end{array}$ & $\begin{array}{l}0,003 \text { **** } \\
(4,118) \\
(0,000)\end{array}$ & $\begin{array}{l}0,003 \text { **** } \\
(6,398) \\
(0,000)\end{array}$ & $\begin{array}{l}0,003 \text { *** } \\
(5,353) \\
(0,000)\end{array}$ & $\begin{array}{l}0,148 \\
(0,335) \\
(0,738)\end{array}$ & $\begin{array}{l}2,104 * * * \\
(4,376) \\
(0,000)\end{array}$ \\
\hline $\mathrm{R}^{2}$ & 0,063 & 0,068 & 0,197 & 0,940 & 0,198 & 0,223 & $-0,005$ & 0,239 \\
\hline $\begin{array}{l}\text { F-statistik } \\
\text { Prob.F- } \\
\text { statistik }\end{array}$ & $\begin{array}{l}3,662 * * * \\
0,014\end{array}$ & $\begin{array}{l}2,332 * * \\
0,037\end{array}$ & $\begin{array}{l}7,330^{* * * *} \\
0,000\end{array}$ & $\begin{array}{l}191.088^{* * * *} \\
0,000\end{array}$ & $\begin{array}{l}10,519^{\text {**** }} \\
0,000\end{array}$ & $\begin{array}{l}6,127 \text { **** } \\
0,000\end{array}$ & $\begin{array}{l}0,782 \\
0,506\end{array}$ & $\begin{array}{l}6,769^{\text {**** }} \\
0,000\end{array}$ \\
\hline $\begin{array}{l}\text { Jumlah } \\
\text { Observasi }\end{array}$ & 120 & 110 & 78 & 73 & 116 & 108 & 119 & 111 \\
\hline Jumlah Bank & 28 & 28 & 23 & 22 & 26 & 26 & 26 & 26 \\
\hline
\end{tabular}

Data di atas merupakan hasil regresi dari estimasi persamaan (5). Kolom (1), (3), (5), dan (7) merupakan pengaruh interaksi kualitas manajemen risiko dan kepemilikan domestik terhadap risiko tanpa variabel kontrol. Kolom (2), (4), (6), dan (8) merupakan regresi interaksi pengaruh komisaris independen dan kepemilikan domestik terhadap risiko dengan variabel kontrol. FD merupakan proporsi kepemilikan domestik sebagai ultimate shareholder di bank. Variabel dependen Z-score diperoleh dari penjumlahan ROA dan CAR dibagi deviasi standar ROA. Risiko sistematis dan risiko spesifik diperoleh dari regresi SIM, menggunakan return saham harian. VaR adalah Value at Risk yang dihitung dengan tingkat signifikansi 5\%, menggunakan metode historic or back simulation dari return saham harian.

$*, * *, * * *$, berturut-turut signifikan pada $10 \%, 5 \%$, dan $1 \%$.

Tabel 14. Regresi Interaksi Jumlah Rapat Komisaris dan Direksi dan Kepemilikan Domestik terhadap Pengambilan Risiko

\begin{tabular}{|c|c|c|c|c|c|c|c|c|}
\hline \multirow{3}{*}{$\begin{array}{l}\text { V.Indepen- } \\
\text { den }\end{array}$} & \multicolumn{8}{|c|}{ Variabel Dependen } \\
\hline & \multicolumn{2}{|c|}{$\begin{array}{c}\text { Risiko Insolvency (Z- } \\
\text { score) }\end{array}$} & \multicolumn{2}{|c|}{$\begin{array}{c}\text { Risiko Sistematis } \\
\left(\beta^{2} \sigma_{\mathrm{m}}^{2}\right)\end{array}$} & \multicolumn{2}{|c|}{$\begin{array}{c}\text { Risiko Spesifik } \\
\left(\sigma^{2} \mathrm{e}_{\mathrm{it}}\right)\end{array}$} & \multicolumn{2}{|c|}{ VaR } \\
\hline & (1) & \begin{tabular}{|l|} 
(2) \\
\end{tabular} & (3) & (4) & (5) & (6) & (7) & (8) \\
\hline $\begin{array}{l}\text { Rapat } \\
\text { (t-stat) } \\
\text { (prob.) }\end{array}$ & $\begin{array}{l}-0,503 \\
(-0,815) \\
(0,416)\end{array}$ & $\begin{array}{l}-0,131 \\
(-0,191) \\
(0,849)\end{array}$ & $\begin{array}{l}-0,0003 \\
(-0,533) \\
(0,595)\end{array}$ & $\begin{array}{l}-0,001 \\
(1,495) \\
(0,140)\end{array}$ & $\begin{array}{l}-0,001 \text { *** } \\
(-3,017) \\
(0,003)\end{array}$ & $\begin{array}{l}-0,002 * * * \\
(-3,006) \\
(0,003)\end{array}$ & $\begin{array}{l}-0,216 \\
(-0,348) \\
(0,728)\end{array}$ & $\begin{array}{l}0,060 \\
(0,048) \\
(0,961)\end{array}$ \\
\hline $\begin{array}{l}\text { DO } \\
\text { (t-stat) } \\
\text { (prob.) }\end{array}$ & $\begin{array}{l}-2,985 \\
(1,143) \\
(0,256)\end{array}$ & $\begin{array}{l}-1,454 \\
(-0,510) \\
(0,611) \\
\end{array}$ & $\begin{array}{l}-0,001 \\
(-0,554) \\
(0,581) \\
\end{array}$ & $\begin{array}{l}-0,004 \\
(-1,608) \\
(0,113)\end{array}$ & $\begin{array}{l}-0,004 * * * * \\
(-2,733) \\
(0,007) \\
\end{array}$ & $\begin{array}{l}-0,007 * * * \\
(-2,743) \\
(0,007) \\
\end{array}$ & $\begin{array}{l}-1,490 \\
(-0,568) \\
(0,570)\end{array}$ & $\begin{array}{l}0,395 \\
(0,075) \\
(0,940)\end{array}$ \\
\hline $\begin{array}{l}\text { Rapat*DO } \\
\text { (t-stat) } \\
\text { (prob.) }\end{array}$ & $\begin{array}{l}0,862 \\
(0,828) \\
(0,409) \\
\end{array}$ & \begin{tabular}{|l|}
0,324 \\
$(0,290)$ \\
$(0,772)$ \\
\end{tabular} & $\begin{array}{l}0,0007 \\
(0,739) \\
(0,462) \\
\end{array}$ & $\begin{array}{l}0,0016 \\
(1,561) \\
(0,124)\end{array}$ & $\begin{array}{l}0,002^{* * * *} \\
(2,729) \\
(0,007) \\
\end{array}$ & \begin{tabular}{|l|}
$0,003 * * *$ \\
$(2,741)$ \\
$(0,007)$ \\
\end{tabular} & $\begin{array}{l}0,579 \\
(0,566) \\
(0,572) \\
\end{array}$ & $\begin{array}{l}-0,154 \\
(-0,075) \\
(0,940)\end{array}$ \\
\hline $\begin{array}{l}N P L \\
\text { (t-stat) } \\
\text { (prob.) }\end{array}$ & & \begin{tabular}{|l|}
$-1,224$ \\
$(-0,381)$ \\
$(0,703)$ \\
\end{tabular} & & $\begin{array}{l}0,010^{* * * *} \\
(3,676) \\
(0,001) \\
\end{array}$ & & \begin{tabular}{|l|}
$-0,002$ \\
$(-1,129)$ \\
$(0,262)$ \\
\end{tabular} & & $\begin{array}{l}-5,181 \\
(-0,929) \\
(0,356)\end{array}$ \\
\hline $\begin{array}{l}L D R \\
\text { (t-stat) } \\
\text { (prob.) }\end{array}$ & & $\begin{array}{l}-0,730 \\
(-0,992) \\
(0,323)\end{array}$ & & $\begin{array}{l}0,001 * * \\
(2,293) \\
(0,025)\end{array}$ & & $\begin{array}{l}0,00004 \\
(0,103) \\
(0,917)\end{array}$ & & $\begin{array}{l}0,355 \\
(0,199) \\
(0,842)\end{array}$ \\
\hline $\begin{array}{l}C I \\
\text { (t-stat) } \\
\text { (prob.) }\end{array}$ & & \begin{tabular}{|l|}
$-0,248$ \\
$(-0,363)$ \\
$(0,717)$ \\
\end{tabular} & & $\begin{array}{l}-0,002 * * * \\
(-3,612) \\
(0,001) \\
\end{array}$ & & \begin{tabular}{|l|}
0,0005 \\
$(1,030)$ \\
$(0,306)$ \\
\end{tabular} & & $\begin{array}{l}0,465 \\
(0,415) \\
(0,679) \\
\end{array}$ \\
\hline $\begin{array}{l}\text { Konstanta } \\
\text { (t-stat.) } \\
\text { (prob.) }\end{array}$ & $\begin{array}{l}6,620 \text { **** } \\
(4,248) \\
(0,000)\end{array}$ & \begin{tabular}{|l}
$6,440 * * * *$ \\
$(3,591)$ \\
$(0,001)$ \\
\end{tabular} & $\begin{array}{l}0,001 \\
(0,777) \\
(0,440) \\
\end{array}$ & $\begin{array}{l}0,003^{* *} \\
(2,294) \\
(0,025)\end{array}$ & $\begin{array}{l}0,004 \text { *** } \\
(3,604) \\
(0,001) \\
\end{array}$ & \begin{tabular}{|l}
$0,005^{* * * * *}$ \\
$(3,196)$ \\
$(0,002)$ \\
\end{tabular} & $\begin{array}{l}1,097 \\
(0,701) \\
(0,485) \\
\end{array}$ & $\begin{array}{l}0,360 \\
(0,111) \\
(0,911)\end{array}$ \\
\hline $\mathrm{R}^{2}$ & 0,062 & 0,002 & $-0,006$ & 0,248 & 0,096 & 0,102 & $-0,008$ & 0,297 \\
\hline $\begin{array}{l}\text { F-statistik } \\
\text { Prob.F- } \\
\text { statistik }\end{array}$ & $\begin{array}{l}2,987^{\text {*** }} \\
0,035\end{array}$ & $\begin{array}{l}1,029 \\
0,412\end{array}$ & $\begin{array}{l}0,859 \\
0,467\end{array}$ & $\begin{array}{l}4,309 * * * \\
0,001\end{array}$ & $\begin{array}{l}4,114^{* * * *} \\
0,008\end{array}$ & \begin{tabular}{|l}
$2,582^{* * *}$ \\
0,024
\end{tabular} & $\begin{array}{l}0,760 \\
0,519\end{array}$ & $\begin{array}{l}2,436^{\text {**** }} \\
0,002\end{array}$ \\
\hline $\begin{array}{l}\text { Jumlah } \\
\text { Observasi }\end{array}$ & 91 & 87 & 64 & 61 & 88 & 85 & 89 & 86 \\
\hline $\begin{array}{l}\text { Jumlah } \\
\text { Bank }\end{array}$ & 21 & 21 & \begin{tabular}{|l|}
17 \\
\end{tabular} & 17 & 20 & 20 & 20 & 20 \\
\hline
\end{tabular}

Data di atas merupakan hasil regresi dari estimasi persamaan (5). Kolom (1), (3), (5), dan (7) merupakan pengaruh interaksi jumlah pertemuan komisaris dan direksi dan kepemilikan domestik terhadap risiko tanpa variabel kontrol. Kolom (2), (4), (6), dan (8) merupakan regresi interaksi pengaruh komisaris independen dan kepemilikan domestik terhadap risiko dengan variabel kontrol. FD merupakan propors kepemilikan domestik sebagai ultimate shareholder di bank. Variabel dependen Z-score diperoleh dari penjumlahan ROA dan CAR dibagi deviasi standar ROA. Risiko sistematis dan risiko spesifik diperoleh dari regresi SIM, menggunakan return saham harian. VaR adalah Value at Risk yang dihitung dengan tingkat signifikansi $5 \%$, menggunakan metode historic or back simulation dari return saham harian.

**, ***, berturut-turut signifikan pada $10 \%, 5 \%$, dan $1 \%$. 
Tabel 15. Hasil Regresi Pengaruh Charter Value terhadap Pengambilan Risiko

\begin{tabular}{|c|c|c|c|c|c|c|c|c|}
\hline \multirow{3}{*}{$\begin{array}{l}\text { V.Indepen- } \\
\text { den }\end{array}$} & \multicolumn{8}{|c|}{ Variabel Dependen } \\
\hline & \multicolumn{2}{|c|}{$\begin{array}{c}\text { Risiko Insolvency } \\
\text { (Z-score) }\end{array}$} & \multicolumn{2}{|c|}{$\begin{array}{l}\text { Risiko Sistematis } \\
\left(\beta^{2} \sigma_{\mathrm{m}}{ }^{2}\right)\end{array}$} & \multicolumn{2}{|c|}{$\begin{array}{c}\text { Risiko Spesifik } \\
\left(\sigma^{2} \mathrm{e}_{\mathrm{it}}\right)\end{array}$} & \multicolumn{2}{|c|}{ VaR } \\
\hline & (1) & (2) & (3) & (4) & (5) & (6) & (7) & (8) \\
\hline $\begin{array}{l}\mathrm{CV} \\
\text { (t-stat) } \\
\text { (prob.) }\end{array}$ & $\begin{array}{l}0,596^{*} \\
(1,641) \\
(0,102)\end{array}$ & $\begin{array}{l}0,189 \\
(0,691) \\
(0,489)\end{array}$ & $\begin{array}{l}-0,001 \text { *** } \\
(-3,375) \\
(0,000)\end{array}$ & $\begin{array}{l}-0,0005^{*} \\
(-1,729) \\
(0,085)\end{array}$ & $\begin{array}{l}-0,001 \text { *** } \\
(-2,835) \\
(0,004)\end{array}$ & $\begin{array}{l}-0,002 * * * \\
(-4,263) \\
(0,000)\end{array}$ & $\begin{array}{l}1,582^{* * *} \\
(6,647) \\
(0,000)\end{array}$ & $\begin{array}{l}1,533 * * * \\
(6,243) \\
(0,000)\end{array}$ \\
\hline $\begin{array}{l}\text { NPL } \\
\text { (t-stat) } \\
\text { (prob.) }\end{array}$ & & $\begin{array}{l}-4,678 * * * \\
(-3,282) \\
(0,001)\end{array}$ & & $\begin{array}{l}0,015^{* * *} \\
(4,972) \\
(0,000)\end{array}$ & & $\begin{array}{l}0,0004 \\
(0,123) \\
(0,902)\end{array}$ & & $\begin{array}{l}-1,883 \text { *** } \\
(-2,806) \\
(0,005)\end{array}$ \\
\hline $\begin{array}{l}L D R \\
\text { (t-stat) } \\
\text { (prob.) }\end{array}$ & & $\begin{array}{l}-0,762^{* *} \\
(-2,254) \\
(0,025)\end{array}$ & & $\begin{array}{l}-0,0001 \\
(-0,727) \\
(0,468)\end{array}$ & & $\begin{array}{l}0,0005 \\
(1,323) \\
(0,186)\end{array}$ & & $\begin{array}{l}-0,831 * * * \\
(-3,785) \\
(0,000)\end{array}$ \\
\hline $\begin{array}{l}C I \\
\text { (t-stat) } \\
\text { (prob.) }\end{array}$ & & $\begin{array}{l}-0,972 * * \\
(-2,138) \\
(0,033)\end{array}$ & & $\begin{array}{l}-0,0004 \text { *** } \\
(-3,856) \\
(0,000)\end{array}$ & & $\begin{array}{l}0,0003 \\
(1,146) \\
(0,252)\end{array}$ & & $\begin{array}{l}-0,073 \\
(-1,214) \\
(0,225)\end{array}$ \\
\hline $\begin{array}{l}\text { Konstanta } \\
\text { (t-stat.) } \\
\text { (prob.) }\end{array}$ & $\begin{array}{l}4,228 \text { **** } \\
(10,111) \\
(0,000) \\
\end{array}$ & $\begin{array}{l}6,192 * * * \\
(11,164) \\
(0,000) \\
\end{array}$ & $\begin{array}{l}0,002 \text { *** } \\
(5,350) \\
(0,000) \\
\end{array}$ & $\begin{array}{l}0,001 \text { *** } \\
(3,206) \\
(0,001) \\
\end{array}$ & $\begin{array}{l}0,002 * * * \\
(5,034) \\
(0,000) \\
\end{array}$ & $\begin{array}{l}0,003 \text { *** } \\
(3,706) \\
(0,000)\end{array}$ & $\begin{array}{l}-1,234 \text { *** } \\
(-4,883) \\
(0,000)\end{array}$ & $\begin{array}{l}-0,406 \\
(-1,193) \\
(0,233) \\
\end{array}$ \\
\hline $\mathrm{R}^{2}$ & 0,006 & 0,089 & 0,069 & 0,156 & 0,026 & 0,103 & 0,142 & 0,233 \\
\hline $\begin{array}{l}\text { F-statistik } \\
\text { Prob.F- } \\
\text { statistik }\end{array}$ & $\begin{array}{l}2,670^{*} \\
0,103\end{array}$ & $\begin{array}{l}6,850 * * * \\
0,000\end{array}$ & $\begin{array}{l}11,395^{* * *} \\
0,001\end{array}$ & $\begin{array}{l}7,870^{* * * *} \\
0,000\end{array}$ & $\begin{array}{l}8,039 * * * \\
0,004\end{array}$ & $\begin{array}{l}7,928 * * * \\
0,000\end{array}$ & $\begin{array}{l}44.188^{* * *} \\
0,000\end{array}$ & $\begin{array}{l}19,718 * * * \\
0,000\end{array}$ \\
\hline $\begin{array}{l}\text { Jumlah } \\
\text { Observasi }\end{array}$ & 252 & 239 & 154 & 149 & 257 & 243 & 261 & 247 \\
\hline $\begin{array}{l}\text { Jumlah } \\
\text { Bank }\end{array}$ & 36 & 36 & 36 & 36 & 36 & 36 & 36 & 36 \\
\hline
\end{tabular}

Data di atas merupakan hasil regresi dari estimasi persamaan (6). Kolom (1), (3), (5), dan (7) merupakan pengaruh charter value terhadap

risiko tanpa variabel kontrol. Kolom (2), (4), (6), dan (8) merupakan regresi pengaruh charter value terhadap risiko dengan variabel kontrol. $\mathrm{CV}$ adalah charter value yang dihitung dengan nilai pasar aset dibagi nilai buku aset. Variabel dependen Z-score diperoleh dari penjumlahan ROA dan CAR dibagi deviasi standar ROA. Risiko sistematis dan risiko spesifik diperoleh dari regresi SIM, menggunakan return saham harian. VaR adalah Value at Risk yang dihitung dengan tingkat signifikansi 5\%, menggunakan metode historic or back simulation dari return saham harian.

*, $* *, * * *$, berturut-turut signifikan pada $10 \%, 5 \%$, dan $1 \%$.

Tabel 16. Regresi Interkasi Charter Value dan Kepemilikan Asing terhadap Pengambilan Risiko

\begin{tabular}{|c|c|c|c|c|c|c|c|c|}
\hline \multirow{3}{*}{$\begin{array}{l}\text { V.Indepen- } \\
\text { den }\end{array}$} & \multicolumn{8}{|c|}{ Variabel Dependen } \\
\hline & \multicolumn{2}{|c|}{$\begin{array}{c}\text { Risiko Insolvency } \\
(Z-s c o r e)\end{array}$} & \multicolumn{2}{|c|}{$\begin{array}{c}\text { Risiko Sistematis } \\
\left(\beta^{2} \sigma_{\mathrm{m}}{ }^{2}\right)\end{array}$} & \multicolumn{2}{|c|}{$\begin{array}{c}\text { Risiko Spesifik } \\
\left(\sigma^{2} \mathrm{e}_{\mathrm{it}}\right)\end{array}$} & \multicolumn{2}{|c|}{ VaR } \\
\hline & (1) & (2) & (3) & (4) & (5) & (6) & (7) & (8) \\
\hline $\begin{array}{l}\mathrm{CV} \\
\text { (t-stat) } \\
\text { (prob.) }\end{array}$ & $\begin{array}{l}-7,903 * * * \\
(-3,607) \\
(0,001)\end{array}$ & $\begin{array}{l}-4,672^{*} \\
(-1,797) \\
(0,076)\end{array}$ & $\begin{array}{l}0,002 \\
(0,737) \\
(0,465)\end{array}$ & $\begin{array}{l}0,006^{*} \\
(1,843) \\
(0,073)\end{array}$ & $\begin{array}{l}-0,002 \\
(-0,730) \\
(0,467)\end{array}$ & $\begin{array}{l}-0,002 \\
(-0,095) \\
(0,924)\end{array}$ & $\begin{array}{l}-0,568 \\
(-0,295) \\
(0,768)\end{array}$ & $\begin{array}{l}2,001 \\
(0,771) \\
(0,442) \\
\end{array}$ \\
\hline $\begin{array}{l}\text { FO } \\
\text { (t-stat) } \\
\text { (prob.) } \\
\end{array}$ & $\begin{array}{l}-12,298^{* * *} \\
(-3,825) \\
(0,000)\end{array}$ & $\begin{array}{l}-8,079 * * \\
(-2,009) \\
(0,048) \\
\end{array}$ & $\begin{array}{l}-0,0002 \\
(-0,036) \\
(0,970) \\
\end{array}$ & $\begin{array}{l}0,007 \\
(1,265) \\
(0,214) \\
\end{array}$ & $\begin{array}{l}-0,006 \\
(-1,038) \\
(0,302) \\
\end{array}$ & $\begin{array}{l}-0,002 \\
(-0,058) \\
(0,953) \\
\end{array}$ & $\begin{array}{l}1,525 \\
2,035 \\
(0,779) \\
\end{array}$ & $\begin{array}{l}2,445 \\
(0,612) \\
(0,542) \\
\end{array}$ \\
\hline $\begin{array}{l}\text { CV*FO } \\
\text { (t-stat) } \\
\text { (prob.) } \\
\end{array}$ & $\begin{array}{l}12,038 \text { *** } \\
(4,007) \\
(0,000) \\
\end{array}$ & $\begin{array}{l}7,502^{* * *} \\
(2,113) \\
(0,038) \\
\end{array}$ & $\begin{array}{l}-0,001 \\
(-0,313) \\
(0,755) \\
\end{array}$ & $\begin{array}{l}-0,007 \\
-1,490 \\
(0,145) \\
\end{array}$ & $\begin{array}{l}0,003 \\
(0,599) \\
(0,550) \\
\end{array}$ & $\begin{array}{l}0,0006 \\
(0,015) \\
(0,987) \\
\end{array}$ & $\begin{array}{l}2,035 \\
(0,779) \\
(0,437) \\
\end{array}$ & $\begin{array}{l}-1,752 \\
(-0,480) \\
(0,632) \\
\end{array}$ \\
\hline $\begin{array}{l}N P L \\
\text { (t-stat) } \\
\text { (prob.) }\end{array}$ & & $\begin{array}{l}-3,960 \\
(-0,852) \\
(0,396)\end{array}$ & & $\begin{array}{l}0,0015 \\
(0,207) \\
(0,836) \\
\end{array}$ & & $\begin{array}{l}0,073 \\
(1,428) \\
(0,157)\end{array}$ & & $\begin{array}{l}4,590 \\
(1,492) \\
(0,139) \\
\end{array}$ \\
\hline $\begin{array}{l}L D R \\
\text { (t-stat) } \\
\text { (prob.) }\end{array}$ & & $\begin{array}{l}-0,362 \\
(-0,751) \\
(0,454) \\
\end{array}$ & & $\begin{array}{l}-0,002 * * * \\
(-2,800) \\
(0,008)\end{array}$ & & $\begin{array}{l}0,003 \\
(0,547) \\
(0,585) \\
\end{array}$ & & $\begin{array}{l}-0,472 \\
(-1,004) \\
(0,318) \\
\end{array}$ \\
\hline $\begin{array}{l}C I \\
\text { (t-stat) } \\
\text { (prob.) } \\
\end{array}$ & & $\begin{array}{l}-2,702 \\
(-3,423) \\
(0,001) \\
\end{array}$ & & $\begin{array}{l}0,0006 \\
(1,086) \\
(0,284) \\
\end{array}$ & & $\begin{array}{l}-0,001 \\
(-0,245) \\
(0,806) \\
\end{array}$ & & $\begin{array}{l}-0,990 \\
(-2,014) \\
(0,047) \\
\end{array}$ \\
\hline $\begin{array}{l}\text { Konstanta } \\
\text { (t-stat.) } \\
\text { (prob.) } \\
\end{array}$ & $\begin{array}{l}13,081^{\text {**** }} \\
(5,634) \\
(0,000) \\
\end{array}$ & $\begin{array}{l}12,702 * * * \\
5,164 \\
(0,000) \\
\end{array}$ & $\begin{array}{l}-0,0009 \\
(-0,235) \\
(0,814) \\
\end{array}$ & $\begin{array}{l}-0,004 \\
(-1,332) \\
(0,191) \\
\end{array}$ & $\begin{array}{l}0,006 \\
(1,384) \\
(0,169) \\
\end{array}$ & $\begin{array}{l}0,004 \\
(0,128) \\
(0,898) \\
\end{array}$ & $\begin{array}{l}0,565 \\
(0,276) \\
(0,782) \\
\end{array}$ & $\begin{array}{l}-1,056 \\
(-0,407) \\
(0,684) \\
\end{array}$ \\
\hline $\mathrm{R}^{2}$ & 0,201 & 0,872 & 0,213 & 0,426 & 0,192 & $-0,042$ & $0,102^{* * * *}$ & 0,092 \\
\hline $\begin{array}{l}\text { F-statistik } \\
\text { Prob.F- } \\
\text { statistik }\end{array}$ & $\begin{array}{l}7,534 * * * \\
0,000\end{array}$ & $\begin{array}{l}84,265^{* * * *} \\
0,000\end{array}$ & $\begin{array}{l}4,701^{* * * *} \\
0,006\end{array}$ & $\begin{array}{l}6,076^{* * * *} \\
0,000\end{array}$ & $\begin{array}{l}7,728^{* * * *} \\
0,000\end{array}$ & $\begin{array}{l}0,450 \\
0,842\end{array}$ & $\begin{array}{l}0,007 \\
4,252\end{array}$ & $\begin{array}{l}2,352^{* *} \\
0,039\end{array}$ \\
\hline $\begin{array}{l}\text { Jumlah } \\
\text { Observasi } \\
\end{array}$ & 79 & 74 & 42 & 42 & 86 & 81 & 86 & 81 \\
\hline $\begin{array}{l}\text { Jumlah } \\
\text { Bank }\end{array}$ & 13 & 13 & 10 & 10 & 13 & 13 & 13 & 13 \\
\hline
\end{tabular}

Data di atas merupakan hasil regresi dari estimasi persamaan (6). Kolom (1), (3), (5), dan (7) merupakan pengaruh charter value terhadap risiko tanpa variabel kontrol. Kolom (2), (4), (6), dan (8) merupakan regresi pengaruh charter value terhadap risiko dengan variabel kontrol. $\mathrm{CV}$ adalah charter value yang dihitung dengan nilai pasar aset dibagi nilai buku aset. Variabel dependen Z-score diperoleh dari penjumlahan ROA dan CAR dibagi deviasi standar ROA. Risiko sistematis dan risiko spesifik diperoleh dari regresi SIM, menggunakan return saham harian. VaR adalah Value at Risk yang dihitung dengan tingkat signifikansi 5\%, menggunakan metode historic or back simulation dari return saham harian.

$*, * *, * *$, berturut-turut signifikan pada $10 \%, 5 \%$, dan $1 \%$. 
Tabel 17. Regresi Interkasi Charter Value dan Kepemilikan Domestik terhadap Pengambilan Risiko

\begin{tabular}{|c|c|c|c|c|c|c|c|c|}
\hline \multirow{3}{*}{$\begin{array}{l}\text { V.Indepen- } \\
\text { den }\end{array}$} & \multicolumn{8}{|c|}{ Variabel Dependen } \\
\hline & \multicolumn{2}{|c|}{$\begin{array}{c}\text { Risiko Insolvency } \\
(\text { Z-score })\end{array}$} & \multicolumn{2}{|c|}{$\begin{array}{c}\text { Risiko Sistematis } \\
\left(\beta^{2} \sigma_{\mathrm{m}}^{2}\right)\end{array}$} & \multicolumn{2}{|c|}{$\begin{array}{c}\text { Risiko Spesifik } \\
\left(\sigma^{2} \mathrm{e}_{\mathrm{it}}\right)\end{array}$} & \multicolumn{2}{|c|}{ VaR } \\
\hline & (1) & (2) & (3) & (4) & (5) & (6) & (7) & (8) \\
\hline $\begin{array}{l}\text { CV } \\
\text { (t-stat) } \\
\text { (prob.) } \\
\end{array}$ & $\begin{array}{l}3,021 * * * \\
(3,832) \\
(0,000) \\
\end{array}$ & $\begin{array}{l}2,285^{*} \\
(1,716) \\
(0,088) \\
\end{array}$ & $\begin{array}{l}0,0006 \\
(0,505) \\
(0,614) \\
\end{array}$ & $\begin{array}{l}-0,002 \\
(-1,136) \\
(0,258) \\
\end{array}$ & $\begin{array}{l}-0,0006 \\
(-0,385) \\
(0,700) \\
\end{array}$ & $\begin{array}{l}0,0001 \\
(0,038) \\
(0,969) \\
\end{array}$ & $\begin{array}{l}4,797 * * * \\
(6,508) \\
(0,000) \\
\end{array}$ & $\begin{array}{l}3,168 * * * \\
(3,128) \\
(0,002) \\
\end{array}$ \\
\hline $\begin{array}{l}\text { DO } \\
\text { (t-stat) } \\
\text { (prob.) } \\
\end{array}$ & $\begin{array}{l}5,140 * * * \\
(4,960) \\
(0,000) \\
\end{array}$ & $\begin{array}{l}3,927 * \\
(1,657) \\
(0,099) \\
\end{array}$ & $\begin{array}{l}0,004 \\
(1,572) \\
(0,118) \\
\end{array}$ & $\begin{array}{l}-0,006 \\
(-1,348) \\
(0,180) \\
\end{array}$ & $\begin{array}{l}0,001 \\
(0,701) \\
(0,483) \\
\end{array}$ & $\begin{array}{l}0,003 \\
(0,839) \\
(0,402) \\
\end{array}$ & $\begin{array}{l}5,221 * * * \\
(6,508) \\
(0,000) \\
\end{array}$ & $\begin{array}{l}3,217^{*} \\
(1,824) \\
(0,070) \\
\end{array}$ \\
\hline $\begin{array}{l}\text { CV*DO } \\
\text { (t-stat) } \\
\text { (prob.) }\end{array}$ & $\begin{array}{l}-5,088^{* * * *} \\
(-4,973) \\
(0,000)\end{array}$ & $\begin{array}{l}-3,887^{*} \\
-1,659 \\
(0,098) \\
\end{array}$ & $\begin{array}{l}-0,003 * \\
(-1,782) \\
(0,077) \\
\end{array}$ & $\begin{array}{l}0,003 \\
(0,973) \\
(0,332) \\
\end{array}$ & $\begin{array}{l}-0,001 \\
(-0,708) \\
(0,479) \\
\end{array}$ & $\begin{array}{l}-0,003 \\
(-0,844) \\
(0,399) \\
\end{array}$ & $\begin{array}{l}-5,166 * * * \\
(-4,076) \\
(0,000)\end{array}$ & $\begin{array}{l}-3,186^{*} \\
(-2,975) \\
(0,069) \\
\end{array}$ \\
\hline $\begin{array}{l}N P L \\
\text { (t-stat) } \\
\text { (prob.) } \\
\end{array}$ & & $\begin{array}{l}-3,703 * * * \\
(-2,500) \\
(0,013) \\
\end{array}$ & & $\begin{array}{l}0,016 \\
(3,987) \\
(0,000) \\
\end{array}$ & & $\begin{array}{l}-0,0006 \\
(-0,151) \\
(0,879) \\
\end{array}$ & & $\begin{array}{l}-1,758^{* * * *} \\
(-2,975) \\
(0,003)\end{array}$ \\
\hline $\begin{array}{l}L D R \\
\text { (t-stat) } \\
\text { (prob.) } \\
\end{array}$ & & $\begin{array}{l}-0,638 \\
(-1,481) \\
(0,140) \\
\end{array}$ & & $\begin{array}{l}0,016 * * * \\
(3,987) \\
(0,000) \\
\end{array}$ & & $\begin{array}{l}0,001 * * \\
(1,969) \\
(0,050) \\
\end{array}$ & & $\begin{array}{l}-0,890^{* * * *} \\
(-2,727) \\
(0,007)\end{array}$ \\
\hline $\begin{array}{l}C I \\
\text { (t-stat) } \\
\text { (prob.) } \\
\end{array}$ & & $\begin{array}{l}-0,665 \\
(-1,305) \\
(0,193) \\
\end{array}$ & & $\begin{array}{l}-0,0005 * * * \\
(-2,979) \\
(0,003)\end{array}$ & & $\begin{array}{l}0,0003 \\
(1,069) \\
(0,286) \\
\end{array}$ & & $\begin{array}{l}0,021 \\
(0,443) \\
(0,657) \\
\end{array}$ \\
\hline $\begin{array}{l}\text { Konstanta } \\
\text { (t-stat.) } \\
\text { (prob.) }\end{array}$ & $\begin{array}{l}1,762 * * \\
(2,164) \\
(0,031) \\
\end{array}$ & $\begin{array}{l}3,621 * * * \\
(2,509) \\
(0,013) \\
\end{array}$ & $\begin{array}{l}0,0003 \\
(0,186) \\
(0,852) \\
\end{array}$ & $\begin{array}{l}0,003 \\
(1,463) \\
(0,146) \\
\end{array}$ & $\begin{array}{l}0,002 \\
(1,341) \\
(0,181) \\
\end{array}$ & $\begin{array}{l}0,0002 \\
(0,102) \\
(0,918) \\
\end{array}$ & $\begin{array}{l}-4,413 * * * \\
(-5,897) \\
(0,000)\end{array}$ & $\begin{array}{l}-1,965^{*} \\
(-1,802) \\
(0,070) \\
\end{array}$ \\
\hline $\mathrm{R}^{2}$ & 0,152 & 0,080 & 0,156 & 0,245 & 0,048 & 0,065 & 0,281 & 0,179 \\
\hline F-statistik & $11,317 * * *$ & $3,396 * * *$ & $7,861 * * *$ & $6,749 * * *$ & $3,886 * * *$ & $2,891 * * *$ & $23,772 * * *$ & $7,004 * * *$ \\
\hline $\begin{array}{l}\text { Prob.F- } \\
\text { statistik }\end{array}$ & 0,000 & 0,003 & 0,000 & 0,000 & 0,010 & 0,010 & 0,000 & 0,000 \\
\hline $\begin{array}{l}\text { Jumlah } \\
\text { Observasi }\end{array}$ & 173 & 165 & 112 & 107 & 171 & 162 & 175 & 29 \\
\hline $\begin{array}{l}\text { Jumlah } \\
\text { Bank }\end{array}$ & 32 & 32 & 28 & 28 & 32 & 32 & 32 & 32 \\
\hline
\end{tabular}

Data di atas merupakan hasil regresi dari estimasi persamaan (6). Kolom (1), (3), (5), dan (7) merupakan regresi interaksi pengaruh charter value dan kepemilikan domestik terhadap risiko tanpa variabel kontrol. Kolom (2), (4), (6), dan (8) merupakan regresi interaksi pengaruh charter value dan kepemilikan domestik terhadap terhadap risiko dengan variabel kontrol. CV adalah charter value yang dihitung dengan nilai pasar aset dibagi nilai buku aset. Variabel dependen Z-score diperoleh dari penjumlahan ROA dan CAR dibagi deviasi standar ROA. Risiko sistematis dan risiko spesifik diperoleh dari regresi SIM, menggunakan return saham harian. VaR adalah Value at Risk yang dihitung dengan tingkat signifikansi 5\%, menggunakan metode historic or back simulation dari return saham harian.

$*, * *, * * *$, berturut-turut signifikan pada $10 \%, 5 \%$, dan $1 \%$ 